Article

\title{
Role of the p38 MAPK/C/EBP $\beta$ Pathway in the Regulation of Phenotype and IL-10 and IL-12 Production by Tolerogenic Bone Marrow-Derived Dendritic Cells
}

\author{
Chantal Guindi, Alexandre Cloutier, Simon Gaudreau, Echarki Zerif, Patrick P. McDonald, \\ Olga Tatsiy, Claude Asselin, Gilles Dupuis $\mathbb{D}^{\circ}$, Denis Gris and Abdelaziz Amrani * \\ Immunology Division, Faculty of Medicine and Health Sciences and Centre de Recherche du CHUS, \\ Université de Sherbrooke, 3001, 12th Avenue North, Sherbrooke, QC J1H 5N4, Canada; \\ chantal.guindi@usherbrooke.ca (C.G.); alexander.cloutier@usherbrooke.ca (A.C.); \\ sgaudreau@ibiosolutions.com (S.G.); echarki.zerif@usherbrooke.ca (E.Z.); \\ patrick.mcdonald@usherbrooke.ca (P.P.M.); olga.tatsiy@usherbrooke.ca (O.T.); \\ claude.asselin@usherbrooke.ca (C.A.); gilles.dupuis@usherbrooke.ca (G.D.); denis.gris@usherbooke.ca (D.G.) \\ * Correspondence: abdelaziz.amrani@usherbrooke.ca; Tel.: +1-(819)-346-1110 (ext. 14854); \\ Fax: +1-(819)-564-5215
}

Received: 8 September 2018; Accepted: 4 December 2018; Published: 7 December 2018

\begin{abstract}
Dendritic cells (DCs) play a major role in innate and adaptive immunity and self-immune tolerance. Immunogenic versus tolerogenic DC functions are dictated by their levels of costimulatory molecules and their cytokine expression profile. The transcription factor C/EBP $\beta$ regulates the expression of several inflammatory genes in many cell types including macrophages. However, little is known regarding the role of $\mathrm{C} / \mathrm{EBP} \beta$ in tolerogenic versus immunogenic DCs functions. We have previously reported that bone marrow-derived DCs generated with GM-CSF (GM/DCs) acquire the signature of semi-mature tolerogenic IL-10-producing DCs as opposed to immunogenic DCs generated with GM-CSF and IL-4 (IL-4/DCs). Here, we show that tolerogenic GM/DCs exhibit higher levels of phosphorylation and enhanced DNA binding activity of C/EBP $\beta$ and CREB than immunogenic IL-4/DCs. We also show that the p38 MAPK/CREB axis and GSK3 play an important role in regulating $C / E B P \beta$ phosphorylation and DNA binding activity. Inhibition of p38 MAPK in GM/DCs resulted in a drastic decrease of C/EBP $\beta$ and CREB DNA binding activities, a reduction of their IL-10 production and an increase of their IL-12p70 production, a characteristic of immunogenic IL-4/DCs. We also present evidence that GSK3 inhibition in GM/DCs reduced C/EBP $\beta$ DNA binding activity and increased expression of costimulatory molecules in GM/DCs and their production of IL-10. Analysis of GM/DCs of C/EBP $\beta^{-/-}$mice showed that $C / E B P \beta$ was essential to maintain the semimature phenotype and the production of IL-10 as well as low CD4 ${ }^{+} \mathrm{T}$ cell proliferation. Our results highlight the importance of the $\mathrm{p} 38 \mathrm{MAPK}-\mathrm{C} / \mathrm{EBP} \beta$ pathway in regulating phenotype and function of tolerogenic GM/DCs.
\end{abstract}

Keywords: tolerogenic bone marrow-derived dendritic cells (BMDCs); CCAAT/enhancer-binding protein beta (C/EBP $\beta$ ); Interleukins 10 and 12 (IL-10; IL-12)

\section{Introduction}

Dendritic cells (DCs) are potent antigen presenting cells (APCs) that play a crucial role in linking innate and adaptive immunity. They detect microorganisms and induce an antigen-specific immunity against pathogens, and can also control and maintain immune tolerance against self antigens [1]. 
DCs normally reside in tissues in an immature form (iDCs) but they differentiate into semi-mature (smDCs) or fully mature (mDCs) DCs following activation of maturation signals. These signals can be induced by host-derived inflammatory cytokines (CD40L, TNF $\alpha$, IL-1, IL-6, and IFN $\gamma$ ), or by microbial products and molecules that stimulate Toll-like receptors [2]. Depending on their state of maturation, DCs exhibit distinct APC functions [3] such as production large amounts of inflammatory cytokines such as TNF $\alpha$, IL-1, IL-6, and IL-12, or anti-inflammatory cytokines such as IL-10 [4]. IL-12 produced by $\mathrm{mDC}$ s drives polarization of $\mathrm{T}$ cells toward a Th1 phenotype, whereas IL-10-producing smDCs inhibit Th1 responses and are involved in the differentiation of regulatory $\mathrm{T}$ cells (Tregs) $[5,6]$. We and others have reported that bone marrow-derived smDCs produce high amounts of IL-10 but low amounts of IL-12 and play a critical role in promoting and maintaining non-inflammatory immune $\mathrm{T}$ cell responses [5-11]. These in vitro findings are corroborated by other studies that showed that in vivo treatment with GM-CSF protects from autoimmune diseases such as T1D and thyroiditis by inducing tolerogenic semi-mature splenic myeloid CD $8 \alpha^{-}$DCs that produced less IL-12 but more IL-10 and facilitated Treg expansion [6,12]. Thus, the state of DC maturation and the balance between inflammatory and anti-inflammatory cytokines determine the type of subsequent acquired immune response.

The mechanisms regulating gene expression associated with DCs maturation and function are not fully understood. The DC maturation program involves activation of the transcription factor NF-KB [13-16] and one or several components of the MAP kinase pathways $[15,17,18]$. It has been reported that NF- $\mathrm{KB}$ is a potent activator of genes encoding costimulatory molecules and pro-inflammatory cytokines during DC maturation [19,20], whereas ERK activation has been associated with promotion of IL-10 production and inhibition of IL-12 production by DCs [21,22]. In connection with these findings, we have reported that inhibition of the MEK1/2-AP-1 pathway reduced the production of IL-10 and enhanced the production of IL-12p70 but had no effect on the phenotype of semi-mature GM/DCs [8]. In addition, it has been reported that ERK was necessary but not sufficient for IL-10 production by smDCs [23]. Consistent with these observations, IL-10 production by TLR-activated DCs was decreased in the presence of ERK inhibitor and by ERK-deficient DCs [24]. Thus, abrogation of ERK activity leads to a reduction, but not abolition of IL-10 expression, suggesting that other pathways may cooperate to IL-10 production by DCs. The transcription factor CCAAT/enhancer binding protein- $\beta(C / E B P \beta)$, a member of the C/EBP family of leucine zipper transcription factors, has been shown to participate in the regulation of many cytokine gene expression associated with inflammatory responses in innate and adaptive immunity [25]. The expression and the activity of C/EBP $\beta$ are regulated by inflammatory mediators such as TNF $\alpha$ and LPS [25]. In macrophages, $\mathrm{C} / \mathrm{EBP} \beta$ is involved in induction of gene encoding inflammatory molecules, including IL-12p70, IL-6, and IL-10 [25,26]. C/EBP $\beta$ has been also suggested to bind to the IL-10 promoter and to induce its transcription in macrophages and $\mathrm{T}$ cells $[27,28]$. Consistent with these findings, LPS-stimulated macrophages of C/EBP $\beta$-deficient mice produced less IL-12p70, IL-6 and TNF $\alpha$ and did not skew immune response toward the Th1 response [29,30]. Furthermore, a defective expression of IL-12p35 but not IL-12p40 gene expression was observed, thereby explaining the defective expression of bioactive IL-12p70 and impaired Th1 response of C/EBP $\beta$-deficient mice [29]. In contrast to these findings, another study reported comparable expression of these cytokines in $\mathrm{C} / \mathrm{EBP} \beta^{+/+}$and C/EBP $\beta^{-/-}$LPS-stimulated macrophages [31].

$\mathrm{C} / \mathrm{EBP} \beta$ DNA binding affinity and specificity are regulated through cooperation with other transcription factors such as the p50 subunit of NF- $\mathrm{kB}, \mathrm{CREB} / \mathrm{ATF}, \mathrm{AP}-1$, and SP1 [26]. It has been shown that the interaction between SP1 and C/EBP $\beta$ cooperatively activated IL-10 gene expression in LPS-stimulated macrophages [28] and that the CREB-C/EBP $\beta$ cascade was essential for induction of the type 2 macrophages anti-inflammatory cytokines such as IL10 [32-37]. CREB activity is mainly regulated through its phosphorylation at serine residue 133 by kinases p38 MAPK [38] and by GSK-3 and, at serine residue 129, by GSK-3 [39]. In this connection, it has been shown that C/EBP $\beta$ phosphorylation by GSK3 and by MAPK induces a conformational change that increases its DNA 
binding activity and transcriptional activation [40]. Interestingly, GSK3 inhibition augments CREB DNA binding, reduces IL-12 production but increases IL-10 production in response to a variety of TLR agonists [39]. Despite the well-documented importance of CREB-C/EBP $\beta$ axis in macrophages, its role in regulating phenotype and anti-inflammatory IL-10 and proinflammatory IL-12p70 production by tolerogenic versus immunogenic DCs is not fully investigated. In the present study, we present evidence that $C / E B P \beta$ and CREB are involved in regulating the balance between IL-10 and IL-12p70 production and in limiting the expression of costimulatory molecules in tolerogenic GM/DCs thereby limiting $\mathrm{T}$ cell proliferation. Furthermore, our study defines the molecular pathways that regulate the p38 MAPK-C/EBP $\beta$ pathway in tolerogenic GM/DCs.

\section{Materials and Methods}

\subsection{Mice}

C57BL/6, BALB/c, and NOD mice were purchased from Taconic (Hudson, NY, USA). NOD-BDC2.5 and NOD.SCID mice were purchased from the Jackson Laboratory (Bar Harbor, ME, USA). 129SV-C57BL/ $6 \mathrm{C} / \mathrm{EBP} \beta^{-/-}$mice were obtained from Dr. Claude Asselin (Université de Sherbrooke) with the agreement of Dr. Peter F Johnson (National Cancer Institute, Frederick, MD, USA). All mice were housed under pathogen-free conditions, in accordance with the guidelines of the Institutional Animal Care Committee of the University of Sherbrooke (Protocols 93-14 and 208-09).

\subsection{Preparation of $B M D C s$}

Bone marrow-derived DCs were generated as described [41] with few modifications. Briefly, bone marrow cells were obtained by flushing femurs and tibia and cultured at $10 \times 10^{6}$ cells $/ 10 \mathrm{~mL}$ of RPMI 1640 medium containing 10\% FBS, glutamine, sodium pyruvate, penicillin/streptomycin, $\beta$-mercaptoethanol $(50 \mu \mathrm{M})$, and $5 \mathrm{ng} / \mathrm{mL}$ of GM-CSF alone or with a combination of GM-CSF and $4.5 \mathrm{ng} / \mathrm{mL}$ of IL-4 (Cedarlane, Burlington, ON, Canada) in Petri dishes (UltiDent scientific, St. Laurent, QC, Canada). At day 3, $10 \mathrm{~mL}$ of fresh medium supplemented with GM-CSF (5 ng/mL) alone or in combination with IL-4 $(4.5 \mathrm{ng} / \mathrm{mL})$ was added to the culture. At day 5, half of the medium was removed and replaced with fresh medium supplemented with GM-CSF ( $5 \mathrm{ng} / \mathrm{mL})$ alone or in combination with IL-4 $(4.5 \mathrm{ng} / \mathrm{mL})$. At day 7, non-adherent cells were gently harvested, pooled, and left unstimulated or exposed to LPS (Sigma-Aldrich, St. Louis, MO, USA; $1 \mu \mathrm{g} / \mathrm{mL}$ ) for $24 \mathrm{~h}$ or $48 \mathrm{~h}$. More than $90 \%$ of these non-adherent cells expressed moderate to high levels of CD11c/MHC-Class II and less than $10 \%$ were Gr1 positive. Bone marrow-derived IL-10/DCs were generated with GM-CSF $(5 \mathrm{ng} / \mathrm{mL}), \mathrm{IL}-4(4.5 \mathrm{ng} / \mathrm{mL})$, and IL-10 $(10 \mathrm{ng} / \mathrm{mL})$ (Cedarlane) following the same protocol.

\subsection{Flow Cytometry and Antibodies}

Anti-CD11c (clone HL3), anti-CD86 (clone GL1), anti-CD40 (Clone 1C10), and anti-CD80 (clone 16-10A1) were purchased from BD Biosciences (Mississauga, ON, Canada). For FACS analysis, DCs were washed with PBS and stained with an anti-CD11c-FITC mAb in combination with anti-CD80-PE-Cy5, anti-CD86-PE-Cy5, or anti-CD40-PE-Cy5 mAbs. Conjugated matched isotypes (Armenian hamster IgG2 or Rat IgG2a) were used as negative controls. Cells were acquired using or FACSCalibur flow cytometer (BD Biosciences) or FACSCanto Instrument (BD Biosciences), and analyzed using the CellQuest Pro (BD Biosciences) or FlowJo (Tree Star, Ashland, OR, USA) software.

\subsection{Proliferation Assays and Cytokine Quantification}

Purified CD4 ${ }^{+} \mathrm{T}$ cells were cultured with in the presence of anti-CD3 and anti-CD28 Abs in the with the addition of GM/DCs or IL-4/DCs for three days at $37^{\circ} \mathrm{C}$. At day 2 of culture, supernatants were collected for cytokine quantification using ELISA kits (R\&D Systems, Minneapolis, MN, USA). Cells were pulsed with $1 \mu \mathrm{Ci}$ of $\left[{ }^{3} \mathrm{H}\right]$ thymidine/well during the last $18 \mathrm{~h}$ of culture and radioactivity was counted. For antigen-specific $\mathrm{CD} 4^{+} \mathrm{T}$ cell proliferation and cytokine production, $\mathrm{CD} 4^{+} \mathrm{CD} 25^{-}$ 
T cells $\left(2 \times 10^{4}\right.$ cells/well $)$ purified from DBC2.5-NOD mice were incubated with NOD GM/DCs $\left(5 \times 10^{3}\right.$ cells/well) that have been pre-incubated with the p38 MAPK inhibitor or vehicle and pulsed with the BDC2.5 mimotope 1040-31 peptide $(0.5 \mu \mathrm{g} / \mathrm{mL})$ (Cederlane, Burlington, ON, Canada). IFN $\gamma$ was quantified in the supernatants after $48 \mathrm{~h}$ of culture using ELISA and proliferation was determined using the thymidine incorporation assay described above.

\subsection{Protein Kinase Inhibition}

BMDCs were pre-incubated with the p38 MAPK inhibitor SB203580 $(10 \mu \mathrm{M})$, the GSK-3 inhibitors SB216763 $(10 \mu \mathrm{M})$ or $\mathrm{LiCl}(10 \mathrm{mM})$ or, with DMSO (vehicle) for $1 \mathrm{~h}$ prior to cell stimulation with LPS $(1 \mu \mathrm{g} / \mathrm{mL})$ as described before [8].

\subsection{Nuclear Extract Preparation}

BMDCs were recovered by centrifugation and cell pellets were re-suspended in cold lysis buffer (10 mM Tris base, $\mathrm{pH} 7.4$, containing $10 \mathrm{mM} \mathrm{NaCl}, 3 \mathrm{mM} \mathrm{MgCl}$, $0.5 \mathrm{mM}$ EGTA, $0.5 \mathrm{mM}$ EDTA, $0.5 \mathrm{mM}$ DTT, and protease and phosphatase inhibitors). After a $10 \mathrm{~min}$ of incubation on ice, an equal volume of the lysis buffer containing $0.2 \% \mathrm{NP}-40$ was added and the extracts were centrifuged at $1500 \times g$ for $5 \mathrm{~min}$ at $4{ }^{\circ} \mathrm{C}$. The cytoplasmic fractions were recovered in the supernatants. The nuclear pellets were re-suspended in lysis buffer containing $10 \%$ glycerol and $\mathrm{NaCl}$ was added to a final concentration of $400 \mathrm{mM}$. After $20 \mathrm{~min}$ incubation on ice, the samples were centrifuged at $13,000 \times g\left(15 \mathrm{~min}, 4^{\circ} \mathrm{C}\right)$ and supernatants were collected and used as nuclear extracts.

\subsection{EMSA and Supershift Assays}

EMSAs were conducted as described [42]. Briefly, nuclear extracts were added to $18 \mu \mathrm{L}$ of total volume of binding buffer $(20 \mathrm{mM}$ Tris Base $\mathrm{pH} 7.5,50 \mathrm{mM} \mathrm{KCl}, 1 \mathrm{mM}$ EDTA, $1 \mathrm{mM}$ DTT, $0.1 \%$ NP40, $5 \%$ glycerol) containing $6 \mu \mathrm{g}$ of acetylated BSA and $0.8 \mu \mathrm{g}$ of poly dI-dC. Then, $10 \mathrm{fmoles}$ of ${ }^{32} \mathrm{P}$-end-labeled oligonucleotide were added to the binding reaction, which was further incubated for $15 \mathrm{~min}$ at room temperature. In the case of supershift experiments, binding reactions were performed in the presence of appropriate antibodies for $30 \mathrm{~min}$ at $4{ }^{\circ} \mathrm{C}$, before addition of labeled oligonucleotides. Samples were electrophoresed on $5.5 \%$ native polyacrylamide gels in Tris-Borate EDTA (TBE) $0.5 \mathrm{X}$ at $4{ }^{\circ} \mathrm{C}$. Dried gels were exposed to autoradiography film at $-80{ }^{\circ} \mathrm{C}$. Oligonucleotides used were $5^{\prime}$-AGAGATTGCCTGACGTCAGAGAGCTAG- $3^{\prime}$ in the case of CREB and $5^{\prime}$-TGCAGATTGCGCAATCTGCA-3' in the case of C/EBP. Antibodies used for supershift assays were anti-C/EBP $\alpha$ (sc-61X), anti-C/EBP $\beta$ (sc-105X), anti-C/EBP $\delta$ (sc-151X), anti-C/EBP $\varepsilon$ (sc-158X), and anti-C/EBP $\gamma$ (sc-7658X) (Santa Cruz Biotechnology, Santa Cruz, CA, USA).

\subsection{Western Blots}

BMDCs were harvested, washed in cold PBS and resuspended in lysis buffer containing Tris base $50 \mathrm{mM}, \mathrm{NaCl} 0.15 \mathrm{M}$, DTT $1 \mathrm{mM}$, Triton X-100 1\% (v/v) and a cocktail of protease and phosphatase inhibitors. Cell lysates were fractionated on 10\% SDS-PAGE gels, transferred to nitrocellulose membrane (Hybond-ECL Amersham Biosciences, Baie d'Urfé, QC, Canada) and incubated overnight with primary antibodies directed against $\mathrm{pC} / \mathrm{EBP} \beta, \mathrm{C} / \mathrm{EBP} \beta, \mathrm{pCREB}$ (Ser133), CREB, $\beta$-actin (Cell Signaling Technology Inc., Danvers, MA, USA), or pCREB (Ser129) (Santa Cruz Biotechnology, Santa Cruz, CA, USA). Blots were then incubated with appropriate secondary antibodies and revealed by enhanced chemiluminescence (GE Health Care, Baie d'Urfé, QC, Canada).

\subsection{Measurements of Cytokine Production}

BMDCs were plated in 96-well culture plates at a density of $1 \times 10^{6}$ cells $/ \mathrm{mL}$ in the absence or the presence of LPS $(1 \mu \mathrm{g} / \mathrm{mL})$ for $24 \mathrm{~h}$. IL-10, IL-12p70, and IL-6 production was quantified in the supernatants using ELISA kits, according to manufacturer's instructions (R\&D Systems). 


\subsection{Real-Time PCR Analysis}

Total RNA was extracted from $5 \times 10^{6}$ BMDCs using Trizol (Invitrogen, Burlington, ON, Canada) and $1 \mu \mathrm{g}$ of the resulting RNA was reverse transcribed using Superscript II (Invitrogen, Burlington, ON, Canada) and OligodT (Promega, Madison, WI, USA). Duplicate real-time PCR reactions for each sample were performed in a volume of $25 \mu \mathrm{L}$ containing $10 \mathrm{ng}$ of cDNA and $1 \mu \mathrm{m}$ of each forward and reverse primers (Supplementary Table S1), using a Quantitect SYBR Green qPCR kit (Qiagen, Montreal, Quebec, Canada) in a Rotorgene 3000 instrument (Corbett Research, Sydney, Australia). Reaction conditions were as follows: $95^{\circ} \mathrm{C}$ for $5 \mathrm{~min}$, followed by 35 cycles $\left(94{ }^{\circ} \mathrm{C}\right.$ for $30 \mathrm{~s}, 60^{\circ} \mathrm{C}$ for $45 \mathrm{~s}, 72{ }^{\circ} \mathrm{C}$ for $60 \mathrm{~s}$ in the case of IL-12p35 and IL-12p40 or $94{ }^{\circ} \mathrm{C}$ for $30 \mathrm{~s}, 64{ }^{\circ} \mathrm{C}$ for $45 \mathrm{~s}, 72{ }^{\circ} \mathrm{C}$ for $60 \mathrm{~s}$ in the case of IL-10 and TGF- $\beta$. Amplification plots were generated using the Rotorgene Amplification software v6.0 (Corbett Research) and fold increases were calculated using the $2^{-\Delta \Delta C t}$ method and normalized using $\beta$-actin expression.

\subsection{Statistics}

Data were analyzed using the GraphPad Prism 6.0 software (GraphPad, San Diego, CA, USA) and are shown as the mean \pm SEM. The Mann-Whitney test was used to detect differences between two groups of nonparametric unpaired samples. When more than two groups were compared, one-way ANOVA with post hoc Bonferroni's test were done. Differences were considered to be statistically significant for $p<0.05$.

\section{Results}

\section{1. $C / E B P \beta D N A$ Binding Activity in $G M / D C s$ and in $I L-4 / D C s$}

We have reported that GM/DCs of NOD mice possess properties of tolerogenic DCs such as exhibition of a semi-mature phenotype and production of high amounts of IL-10 and low amounts of IL-12 [8]. We also have reported that the ERK1/2 MAP kinase was important but not sufficient to regulate the IL-10/IL-12p70 balance but was not involved in regulating DC maturation. C/EBP $\beta$ has been also shown to be a critical regulator of the expression of IL-10 and IL-12p35 in macrophages [29,43] but its role in DCs maturation status and IL-10 and IL-12p70 production has not been fully investigated. In a first series of experiments, we examined (EMSA) C/EBP DNA binding activity in nuclear extracts prepared from GM/DCs and IL-4/DCs of NOD and BALB/c mice. Results showed a weak C/EBP DNA binding activity in unstimulated GM/DCs and IL-4/DCs of both strains of mice (Figure 1A). However, following LPS-stimulation, C/EBP DNA binding activity was strongly increased in GM/DCs but not in IL-4/DCs from both strains of mice (Figure 1A). Similar results were obtained with bone morrow-derived DCs of C57BL/ 6 mice (Figure 1B). To investigate whether the strong C/EBP DNA binding activity observed in the case of GM/DCs was associated with tolerogenic potential of DCs, C/EBP DNA binding activity was analyzed in IL-10/DCs (generated in the presence of GM-CSF, IL-4, and IL-10) of NOD and C57BL/ 6 mice that have been reported to possess tolerogenic properties [44-47]. Interestingly, strong C/EBP DNA binding activity was also observed in LPS-stimulated IL-10/DCs of NOD and C57BL/ 6 mice (Figure 1B). These data indicated that increased C/EBP binding activity in tolerogenic GM/DCs and IL-10/DCs of NOD mice was congruent with findings in BALB/c or C57BL/ 6 mice, suggesting that these results held true across these three strains of mice. To determine which one of the $\mathrm{c} / \mathrm{EBP}$ isoforms bound to C/EBP consensus sequence, supershift assays using nuclear extracts of LPS-stimulated GM/DCs were performed. Results revealed that only the anti-C/EBP $\beta$ antibody shifted the DNA binding complex in GM/DCs' nuclear extracts prepared from NOD and BALB/c mice (Figure 1C). Furthermore, a time course study (Figure 1D) showed that C/EBP $\beta$ DNA binding activity in LPS-stimulated GM/DCs was increased at $1 \mathrm{~h}$ post-stimulation, peaked at $8 \mathrm{~h}$, and progressively decreased thereafter. However, binding activity remained higher at all time points compared to the very weak DNA binding activity in IL-4/DCs. Western blot analysis showed that the levels of CEBP $\beta$ and phosphorylated CEBP $\beta$ were higher in LPS-stimulated GM/DCs and IL-10/DCs 
than in LPS-stimulated IL-4/DCs (Figure 1E,F). Moreover, C/EBP $\beta$ protein was found in the nuclear extracts and its expression was higher in GM/DCs than in IL-4/DCs (Supplementary Figure S1). Together, these results showed an increased C/EBP $\beta$ phosphorylation that correlated with enhanced DNA binding activity in LPS-stimulated tolerogenic GM/DCs but not in immunogenic LPS-stimulated IL-4/DCs.

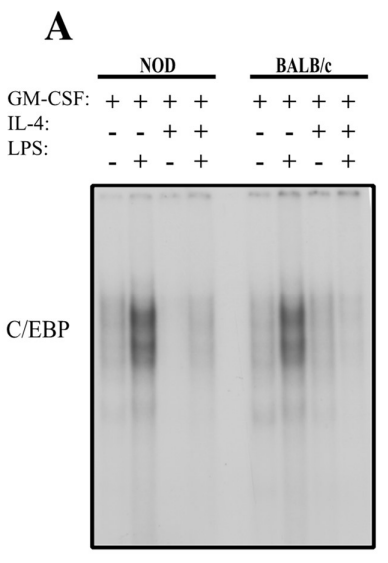

D

GM/DCs

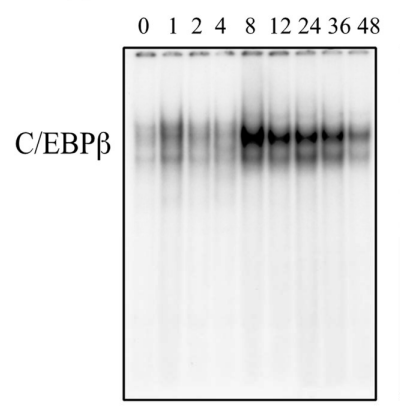

B

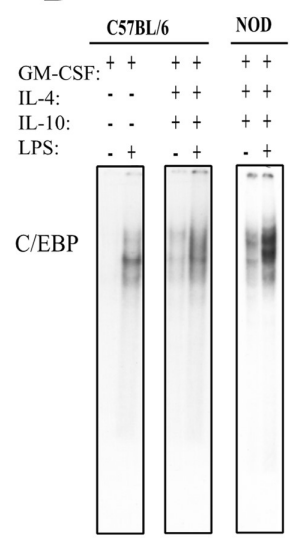

IL-4/DCs

$\begin{array}{llllll}0 & 1 & 2 & 4 & 8 & 12243648\end{array}$

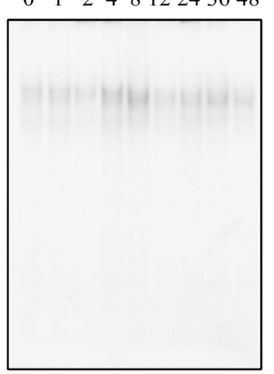

C

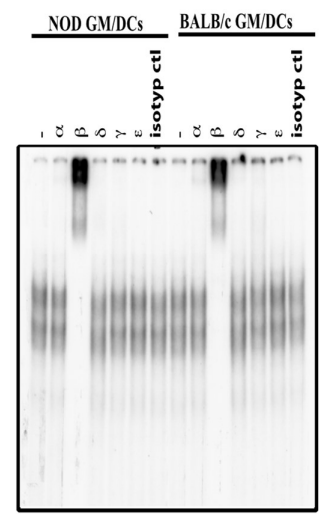

E

GM-CSF: $^{+}+++++$

IL-4: $\cdot++++$

LPS: $+i^{-}+{ }^{+}+$

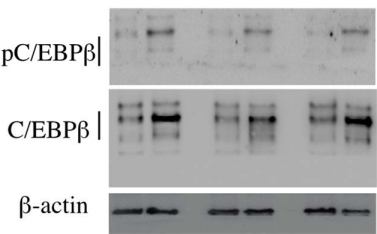

F
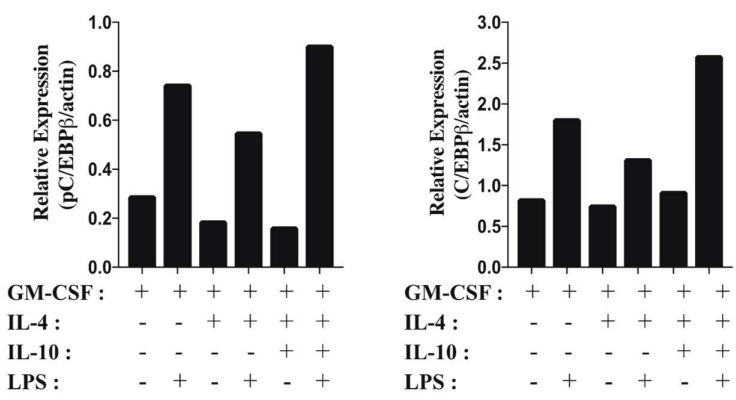

Figure 1. Increased $C / E B P \beta$ expression and DNA binding activity in LPS-stimulated GM/DCs. (A) Bone marrow-derived GM/DCs and IL-4/DCs were generated from NOD and BALB/c mice and left unstimulated or stimulated with LPS $(1 \mu \mathrm{g} / \mathrm{mL}$ for $48 \mathrm{~h})$. Nuclear extracts were subjected to EMSA assays to assess C/EBP binding activity. (B) Bone marrow-derived GM/DCs and IL-10/DCs (generated with GM-CSF + IL-4 + IL-10) from C57BL/6 and NOD mice were left unstimulated or stimulated with LPS $(1 \mu \mathrm{g} / \mathrm{mL}$ for $48 \mathrm{~h})$. Nuclear extracts were prepared and C/EBP binding activity was determined by EMSA assays (C) Supershift analyses were performed with nuclear extracts obtained from LPS-stimulated GM/DCs of NOD and BALB/c mice, as described in the Material and Methods section of the body of the text. (D) C/EBP $\beta$ DNA binding activity was monitored by EMSA, using nuclear extracts from LPS-stimulated GM/DCs and IL-4/DCs from NOD mice at the indicated times. (E) Western blot analysis of $\mathrm{pC} / \mathrm{EBP} \beta$ (Thr188) and C/EBP $\beta$ levels in cell lysates from LPS stimulated GM/DCs and IL-4/DCs. (F) Quantitative analysis of data in Figure 1E normalized to loading control $(\beta$-actin). Data are representative of a minimum of $2-3$ independent experiments. 
3.2. Effect of $p 38$ MAPK and GSK3 Inhibitors on C/EBP $\beta$ and CREB Phosphorylation and DNA Binding Activity in GM/DCs

It has been reported that phosphorylation of C/EBP $\beta$ by MAPK and, subsequently, by GSK3 $\beta$ leads to the acquisition of DNA binding activity [48]. To determine the contribution of each kinase on C/EBP $\beta$ DNA binding activity, GM/DCs were treated with the p38 MAPK inhibitor SB203580 or with the GSK3 inhibitor SB216763 prior to stimulation with LPS. Results of EMSA experiments showed that both inhibitors reduced C/EBP $\beta$ DNA binding activity (Figure 2A). The downstream targets of p38 MAPK include a wide array of cytoplasmic and nuclear factors including CREB, which is known to induce C/EBP $\beta$ transcription following its phosphorylation on serine residues [32,37]. Western blot analysis clearly showed a rapid and intense CREB phosphorylation at Ser133 and Ser129 in GM/DCs, as compared to low levels of CREB phosphorylation and expression in IL-4/DCs (Figure 2B). Next, we investigated whether the p38 MAPK inhibitor SB203580 would affect CREB DNA binding activity in GM/DCs. Results showed that the strong CREB DNA binding activity observed in LPS-stimulated GM/DCs was drastically reduced in the presence of the p38 MAPK inhibitor SB203580 whereas the GSK3 inhibitor SB216763 had no effect (Figure 2C). Consistent with these observations, a drastic decrease in the levels of protein and phosphorylation levels at Thr188 of C/EBP $\beta$ was observed in the presence of the p38 MAPK inhibitors SB203580 (Figure 2D) and SB202190 (Figure 2E). In contrast, addition of the GSK-3 $\beta$ inhibitor led to a slight decrease of C/EBP $\beta$ phosphorylation and $\mathrm{C} / \mathrm{EBP} \beta$ protein levels, particularly the LIP isoform (Figure 2D). These data indicated that both the p38 MAPK-CREB axis and GSK3 $\beta$ play a critical role in inducing C/EBP $\beta$ phosphorylation and DNA binding activity in tolerogenic GM/DCs.

A

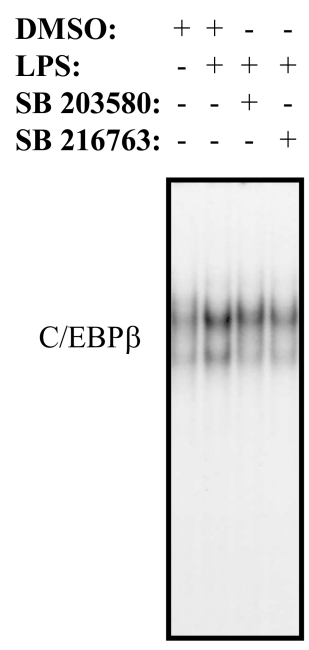

B

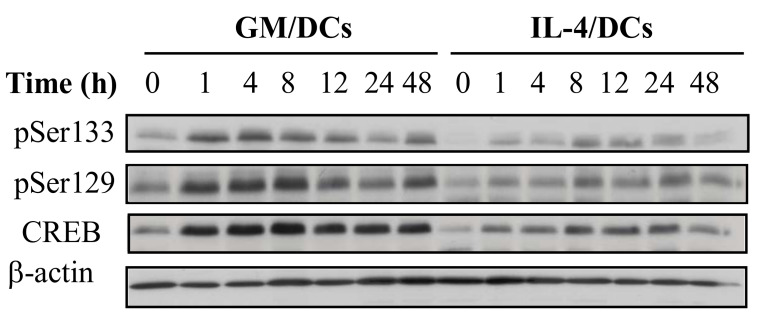

Figure 2. Cont. 
C

DMSO: $\quad++--$
LPS: $\quad-+++$
SB 203580: - - + -
SB 216763: - - - +

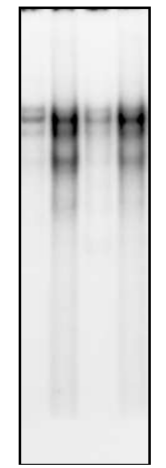

D

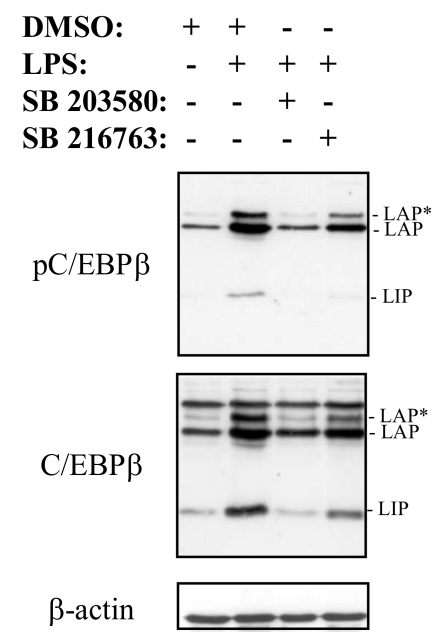

$\mathbf{E}$

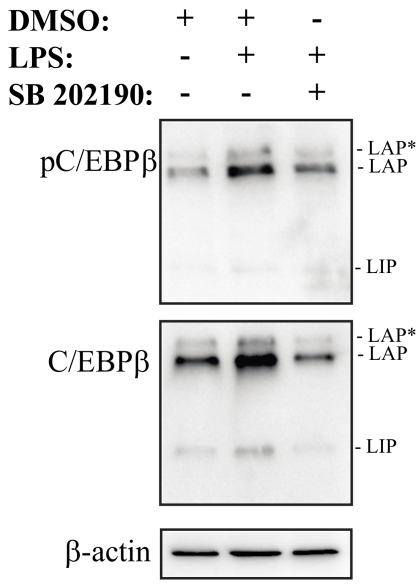

Figure 2. Role of p38 MAPK/CREB and GSK3b/CREB axis in the activation and DNA binding activity of C/EBP $\beta$ in GM/DCs. Bone marrow-derived GM/DCs were preincubated with inhibitors of p38 MAPK (SB203580, $10 \mu \mathrm{M})$, p38 MAPK (SB202190, $1 \mu \mathrm{M})$, GSK3 (SB 216763, $10 \mu \mathrm{M}$ ), or vehicle (DMSO) for $1 \mathrm{~h}$ before stimulation with LPS $(1 \mu \mathrm{g} / \mathrm{mL}$ for $8 \mathrm{~h}$ ). (A) C/EBP $\beta$ DNA binding activity in nuclear extracts were analyzed by EMSA. (B) Western blot analysis of the levels of phosphorylated (Ser129, Ser133) and total CREB in whole cell lysates at the indicated times (hours) after LPS stimulation $(1 \mu \mathrm{g} / \mathrm{mL})$. (C) CREB DNA binding activity in nuclear extracts were analyzed by EMSA. (D,E) Western blot analysis of the levels of phosphorylated (Thr188) and total C/EBP $\beta$ in whole cell lysates after $8 \mathrm{~h}$ of LPS stimulation $(1 \mu \mathrm{g} / \mathrm{mL})$. Data are representative of two independent experiments.

\subsection{Functional Impact of Inhibition of C/EBP $\beta$ and CREB DNA Binding on Cytokine Production and} Phenotype of Tolerogenic GM/DCs

$\mathrm{C} / \mathrm{EBP} \beta$ is involved in the production of IL-10 [43] and IL-12 by regulating IL-12p35 and IL-12p40 gene expression [29] in macrophages. We therefore investigated whether inhibition of C/EBP $\beta$ binding activity in LPS-stimulated GM/DCs would affect gene expression and production of IL-10 and IL-12p70 cytokines. In agreement with our previous report [8], results showed that LPS induced a significant increase in mRNA expression and secretion of IL-10, whereas it only promoted a modest induction of IL-12p35 expression and IL-12p70 secretion (Figure 3). Interestingly, pretreatment with the 338 MAPK inhibitor SB203580 significantly $(p<0.05)$ reduced IL-10 gene expression and secretion (Figure 3A,D) whereas it markedly $(p<0.001)$ enhanced IL-12p35 gene expression and IL-12p70 secretion (Figure 3B,E). In contrast, a pretreatment with the GSK3 inhibitor SB216763 significantly $(p<0.001)$ enhanced IL-10 mRNA expression and protein secretion (Figure 3A,D). The addition of SB216763 led low IL-12p35 mRNA expression at $4 \mathrm{~h}$ followed by enhanced IL-12p35 mRNA expression at $12 \mathrm{~h}$ of LPS stimulation, although to a lesser extent than p38 MAPK inhibition (Figure 3B). In contrast, SB216763 significantly reduced IL-12p70 production, suggesting that GSK3 inhibition results in downregulation of IL-12p70 production through inhibition of IL-12p35 translation (Figure 3E). No significant changes were observed in IL-12p40 mRNA expression in the presence of SB203580 or SB216763 inhibitors (Figure 3C). Treatment with LiCl, another GSK3 inhibitor, resulted in a similar switch in the profile of IL-10 and IL-12p70 secretion, as observed with SB216763 inhibitor (Supplementary Figure S2). Taken together, these results suggested that p38 MAPK and GSK3 kinases are involved in the regulation of the CREB/C/EBP $\beta$ axis, which appears to be important in fine-tuning the balance between IL-10 and IL-12p70 production in GM/DCs. We next analyzed the expression of costimulatory molecules CD80, CD86, and CD40 to determine whether the production of IL-10 and IL-12p70 by GM/DCs incubated in the presence of p38 MAPK and GSK3 inhibitors was accompanied by an increased maturation of GM/DCs upon LPS stimulation. Results of FACS analysis showed that 
the use of the p38 MAPK inhibitor SB203580 resulted in a weak increase in expression of CD86 but not CD80 or CD40 (Figure 4A). In marked contrast, the LiCl-dependent inhibition of GSK3 strongly enhanced the expression of CD80 and CD86 but not CD40 (Figure 4B). This mature phenotype of LPS-stimulated GM/DCs acquired in the presence of GSK3 inhibitor was similar to that of mature LPS-stimulated IL-4/DCs generated in the presence of GM-CSF and IL-4 (Figure 4C). Together, these data strongly suggested that the $\mathrm{p} 38 \mathrm{MAPK} / \mathrm{CREB} / \mathrm{C} / \mathrm{EBP} \beta$ axis regulates IL-10 and IL-12 production by LPS-stimulated GM/DCs and further suggested that the p38MAPK/GSK3 $\beta-C / E B P \beta$ axis was involved in regulating GM/DCs phenotype and function.

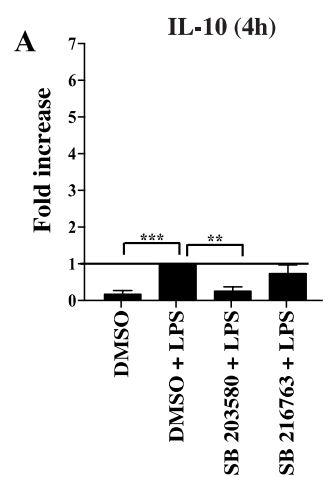

B

IL-12p35 (4 h)
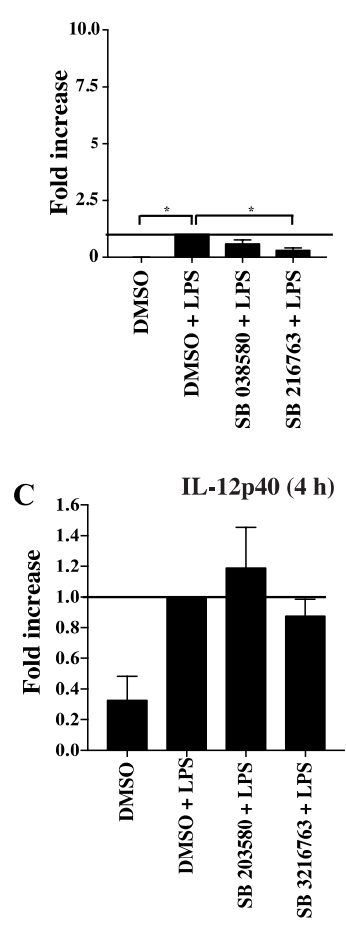

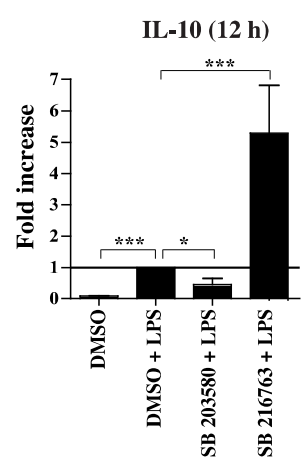

IL-12p35 (12 h)
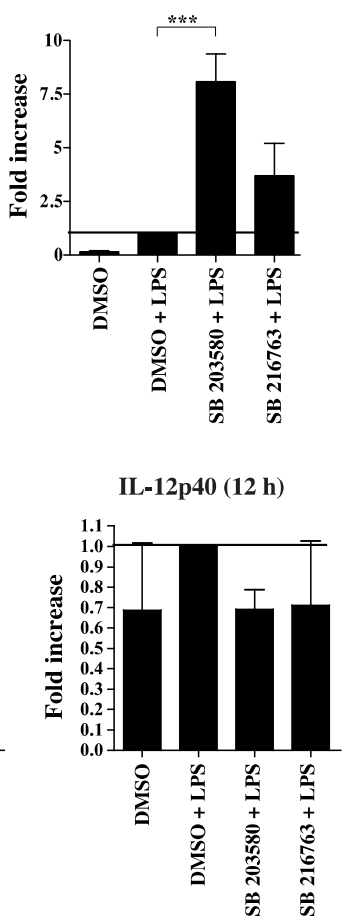

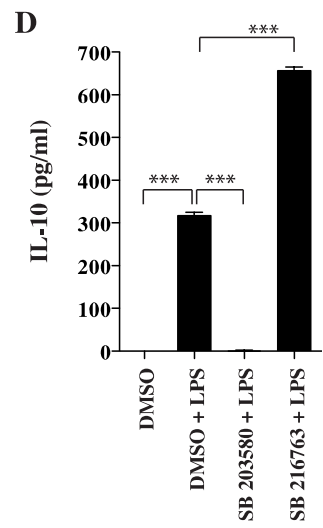

$\mathbf{E}$

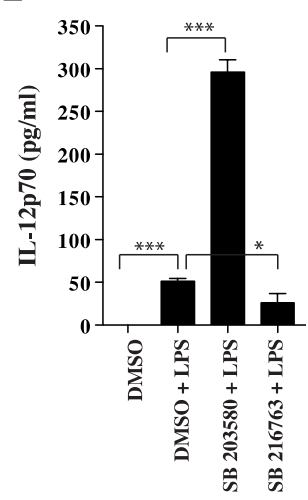

Figure 3. Role of p38 MAPK/CREB and GSK3 $\beta$ /CREB axis in regulating IL-10 and IL-12 in GM/DCs. Bone marrow-derived GM/DCs were preincubated for $1 \mathrm{~h}$ in the presence of a p38 MAPK (SB203580, $10 \mu \mathrm{M}$ ) or a GSK3 (SB216763, $10 \mu \mathrm{M}$ ) inhibitor or, vehicle (DMSO) before being exposed to LPS $(1 \mu \mathrm{g} / \mathrm{mL}$ for $4 \mathrm{~h}$ or $12 \mathrm{~h}$ ). Total RNA was isolated and the expression of IL-10 (A), IL-12p35 (B) and IL-12p40 (C) was determined by real-time PCR. Fold increases are calculated with reference to vehicle $(\mathrm{DMSO})+$ LPS conditions. Data are representative of five or six independent experiments. In the case of cytokine release essays, GM/DCs were preincubated for $1 \mathrm{~h}$ with SB203580 (10 $\mu \mathrm{M}), \mathrm{SB} 216763$ $(10 \mu \mathrm{M})$ or, with vehicle (DMSO), before being exposed to LPS $(1 \mu \mathrm{g} / \mathrm{mL}$ for $24 \mathrm{~h})$. IL-10 (D) and IL-12p70 (E) production was quantified in cell supernatants by ELISA. Data are representative of three independent experiments. Results are shown as the mean \pm SEM. The asterisks $\left({ }^{*}\right)$ correspond to $p<0.05\left(^{*}\right), p<0.01\left(^{* *}\right)$, and $\left.p<0.001{ }^{* * *}\right)$, one-way ANOVA with post hoc Bonferroni's test. 
A

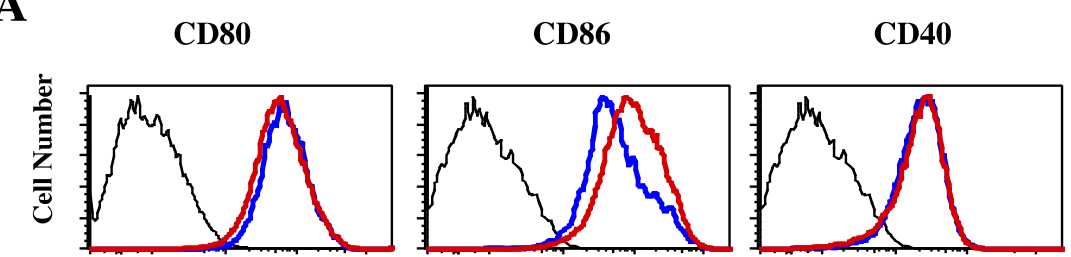

B
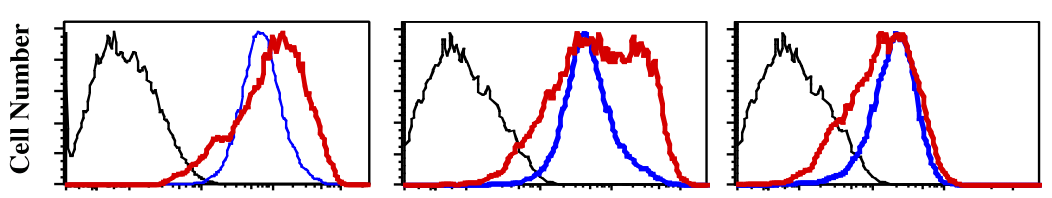

C
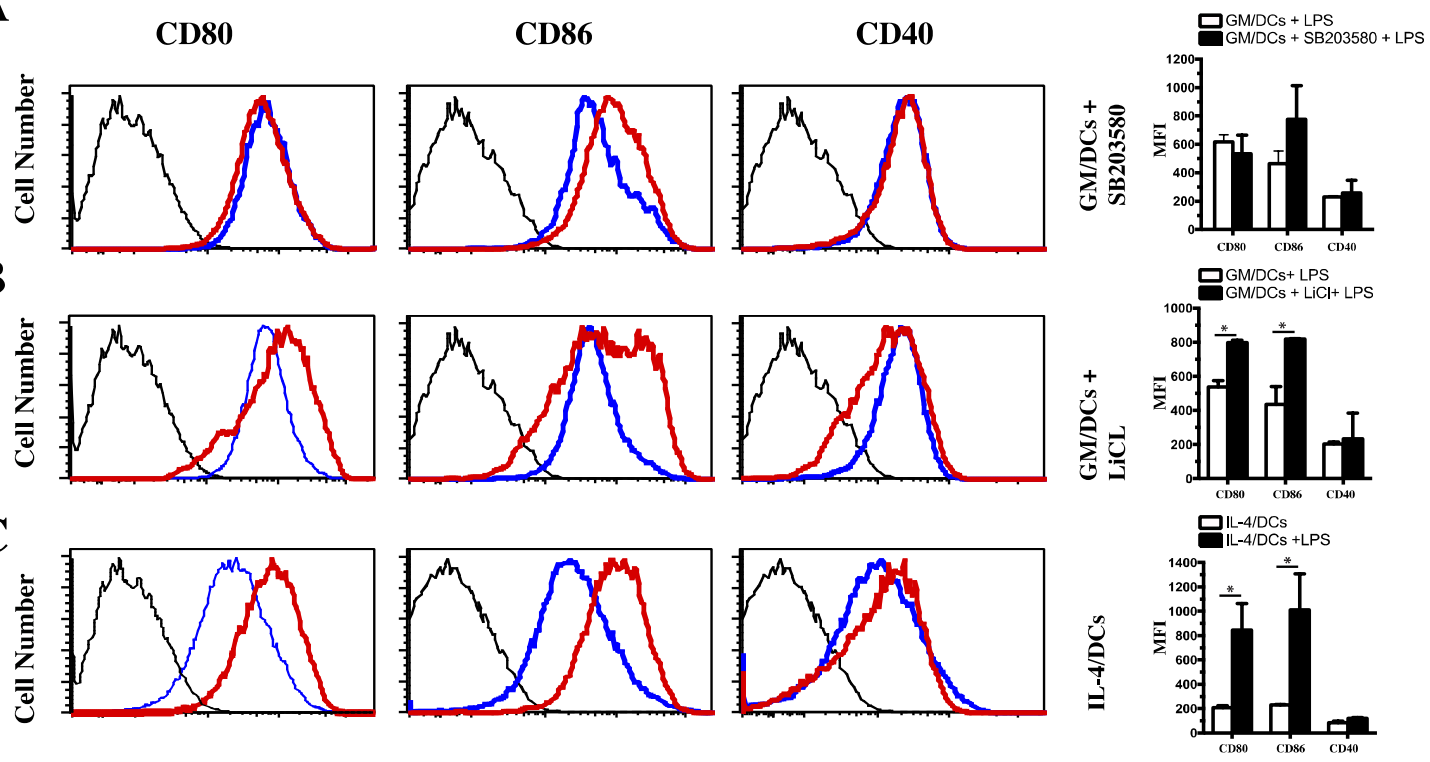

Figure 4. Role of $338 \mathrm{MAPK} / \mathrm{CREB}$ and GSK3b/CREB axis in regulating GM/DCs maturation status. Bone marrow-derived GM/DCs were preincubated with vehicle (DMSO, Blue thin line) or (A) p38 MAPK inhibitor (SB203580. $10 \mu \mathrm{M}$, red line) or (B) $\mathrm{LiCl}$ (10 mM, red line) before being exposed to with LPS $(1 \mu \mathrm{g} / \mathrm{mL}$ for $48 \mathrm{~h})$. Cells were harvested and the expression of CD80, CD86, and CD40 molecules was analyzed by gating on CD11 $\mathrm{c}^{+}$cells using flow cytometry. (C) Bone marrow-derived IL-4/DC were left unstimulated (blue line) or were exposed to LPS $(1 \mu \mathrm{g} / \mathrm{mL}$ for $48 \mathrm{~h}$ ) (red line) and analyzed by flow cytometry. For all the panels, isotype controls are shown (dashed thin line). Expression levels of CD80, CD86, and CD40 cell surface markers are illustrated as mean fluorescence intensities (MFIs) are shown at right-hand sides of panels. Data are representative of two to four independent experiments. * $p<0.05$, nonparametric unpaired Mann-Whitney test.

\subsection{Effect of C/EBP $\beta$ Deficiency on the Phenotype of GM/DCs}

To further evaluate the role of $C / E B P \beta$ in regulating DCs maturation status, GM/DCs were derived from bone marrow of $129 \mathrm{SV} / \mathrm{C} 57 \mathrm{BL} 6 \mathrm{C} / \mathrm{EBP} \beta^{-/-}\left(\mathrm{C} / \mathrm{EBP} \beta^{-/-}\right)$mice and their littermate controls 129SV/C57BL6 C/EBP $\beta^{+/+}\left(\mathrm{C} / \mathrm{EBP} \beta^{+/+}\right)$and were stimulated or not with LPS. Results of FACS analysis showed that unstimulated GM/DCs from both strains of mice expressed low levels of CD80 and CD40 whereas the level of CD86 was higher in GM/DCs from C/EBP $\beta$ deficient mice (Figure 5A,B). In agreement with our previous report [8], LPS-stimulated GM/DCs of C/EBP $\beta^{+/+}$ mice displayed a semi-mature phenotype characterized by a weak increase of expression of CD80 and CD86 markers (Figure 5A,D). Interestingly, LPS-stimulated GM/DCs derived from C/EBP $\beta^{-/-}$ mice displayed a fully mature phenotype, as indicated by enhanced expression of CD80 and CD86 compared to GM/DCs of C/EBP $\beta^{+/+}$mice (Figure 5C,D). In addition, the levels of CD80 and CD86 in LPS-stimulated GM/DCs of C/EBP $\beta^{-/-}$mice were similar to those expressed by LPS-stimulated IL-4/DCs derived from C/EBP $\beta^{+/+}$mice (Figure $4 \mathrm{C}$ ). These data suggest that $\mathrm{C} / \mathrm{EBP} \beta$ plays a determining role in limiting GM/DCs maturation. 


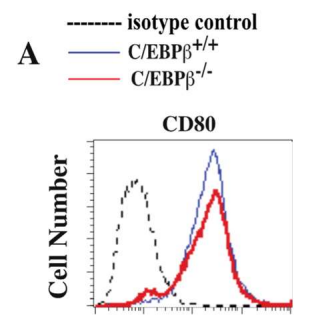

C

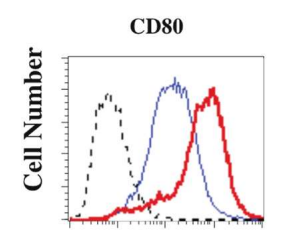

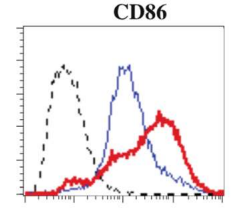

GM/DCs (no LPS)

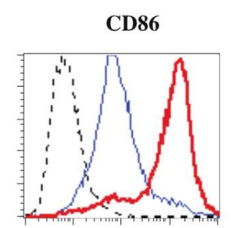

GM/DCs (with LPS)
B

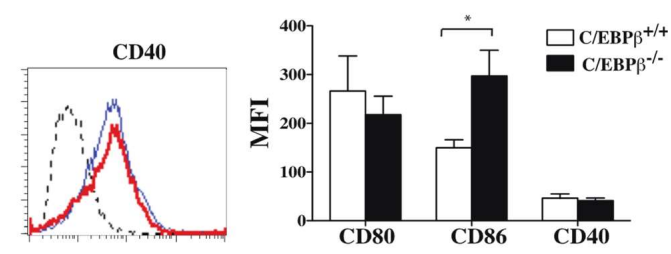

D
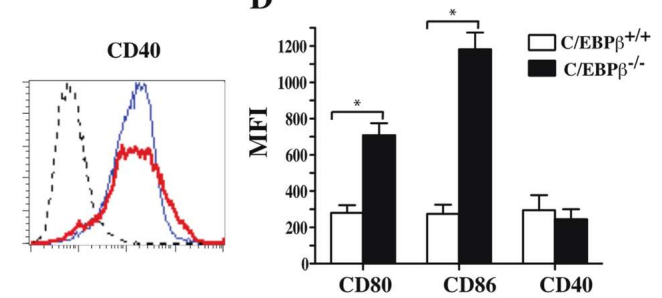

Figure 5. Effect of $\mathrm{C} / \mathrm{EBP} \beta$ deficiency on the maturation status of GM/DCs. Bone marrow-derived $\mathrm{GM} / \mathrm{DC}$ generated from $\mathrm{C} / \mathrm{EBP} \beta^{+/+}$mice (Blue line) and $\mathrm{C} / \mathrm{EBP} \beta^{-/-}$mice (red line), were left unstimulated (A) or exposed to LPS $(1 \mu \mathrm{g} / \mathrm{mL}$ for $48 \mathrm{~h})(\mathbf{C})$ and were stained and analyzed for CD80, CD86, and CD40 expression on $\mathrm{CD}_{11 \mathrm{c}^{+}}$cells using flow cytometry. Dashed thin lines represent labeling with isotype control antibodies. (B and D) Expression levels of CD80, CD86, and CD40 cell surface markers on unstimulated (B) and LPS exposed (D) GM/DCs are illustrated as mean fluorescence intensities (MFIs). The results are representative of three independent experiments. ${ }^{*} p<0.05$, nonparametric unpaired Mann-Whitney test.

\subsection{Role of $C / E B P \beta$ in Regulating GM/DCs Function}

We next sought to determine the consequence of $C / E B P \beta$ deficiency on mRNA levels and secreted IL-10 and IL-12 in GM/DCs. Results showed that LPS-stimulated GM/DCs of C/EBP $\beta^{+/+}$mice expressed more IL-10 mRNA transcripts than IL-12p35 mRNA transcripts (Figure 6). The expression levels of both transcripts were dramatically reduced in LPS-stimulated GM/DCs derived from $\mathrm{C} / \mathrm{EBP} \beta^{-/-}$mice (Figure $\left.6 \mathrm{~A}, \mathrm{~B}\right)$. Levels of IL-12p40 mRNA were transiently increased in GM/DCs from $C / E B P \beta^{-/-}$mice (Figure $6 \mathrm{C}$ ). In agreement with the reported impaired expression of IL-6 in C/EBP $\beta$-deficient macrophages [29], our data showed a significant decrease of IL-6 mRNA in $\mathrm{GM} / \mathrm{DCs}$ of $\mathrm{C} / \mathrm{EBP} \beta^{-/-}$mice as compared to GM/DCs of $\mathrm{C} / \mathrm{EBP} \beta^{+/+}$mice (Figure $6 \mathrm{D}$ ). Analysis of secreted cytokines showed that, following $24 \mathrm{~h}$ of LPS stimulation, GM/DCs of C/EBP $\beta^{-/-}$mice produced lower amounts of IL-10 than GM/DCs from $\mathrm{C} / \mathrm{EBP} \beta^{+/+}$mice (Figure $6 \mathrm{E}$ ). Furthermore, GM/DCs of C/EBP $\beta^{-/-}$mice produced significantly lower amounts of IL-12p70 than GM/DCs of $\mathrm{C} / \mathrm{EBP} \beta^{+/+}$mice (Figure $6 \mathrm{~F}$ ). Similarly, IL-6 production by GM/DCs of C/EBP $\beta^{-/-}$mice was drastically reduced as compared to GM/DCs of $\mathrm{C} / \mathrm{EBP} \beta^{+/+}$mice (Figure $6 \mathrm{G}$ ). Two groups have recently reported that, $\mathrm{C} / \mathrm{EBP} \beta$ plays an essential role in limiting proliferation of $\mathrm{CD} 4^{+} \mathrm{T}$ cells and IFN $\gamma$ production in the case of lymphoma-educated DCs and Gr1+CD11b MDSC [49,50]. These findings led us to investigate the impact of $\mathrm{C} / \mathrm{EBP} \beta$ on the capacity of tolerogenic GM/DCs to induce $\mathrm{CD} 4^{+}$ $\mathrm{T}$ cells proliferation as well as IFN $\gamma$ production. Results showed islet-specific BDC-2.5 CD4 ${ }^{+} \mathrm{T}$ cell proliferation and IFN $\gamma$ production were significantly increased when cultured in the presence of peptide-pulsed LPS-stimulated GM/DCs that has been pretreated with the p38MAPK inhibitor SB203580 as compared to BDC2.5 CD4 ${ }^{+}$T cells cultured with peptide-pulsed LPS-stimulated GM/DCs pretreated with vehicle (Figure 7A). Similarly, $\mathrm{CD}^{+} \mathrm{T}$ cell proliferation and IFN $\gamma$ production were significantly increased in the presence of LPS-stimulated C/EBP $\beta^{-/-} \mathrm{GM} / \mathrm{DC}$ s as compared to the absence of proliferation and IFN $\gamma$ production by $\mathrm{CD}^{+} \mathrm{T}$ cells co-cultured in the presence of LPS-stimulated GM/DCs (Figure 7B). These data were presented as evidence that C/EBP $\beta$ was an important transcription factor that controlled not only IL-10 and IL-12 gene and protein expression 
but that it also influenced the capacity of GM/DCs to induce $\mathrm{CD} 4^{+} \mathrm{T}$ proliferation and IFN $\gamma^{+}$effector phenotype. Overall, these results suggest that $c / E B P \beta$ is a transcription factor that plays an essential role in establishing a GM/DCs tolerogenic program.

A

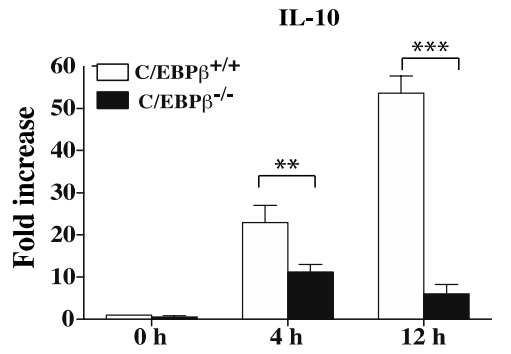

B

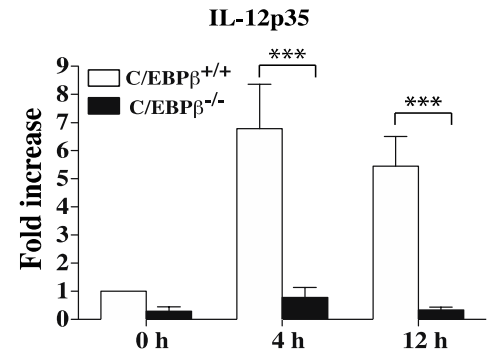

C

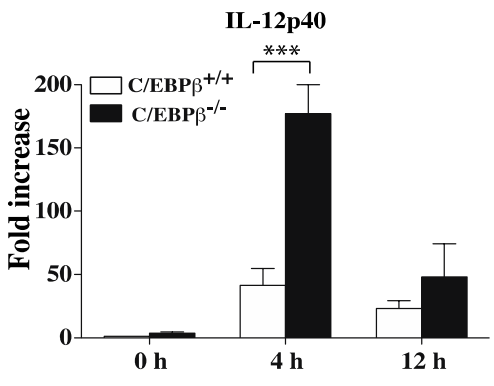

D

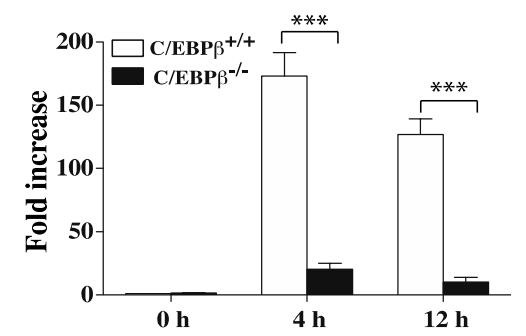

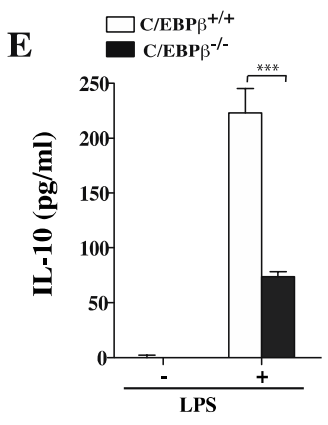

F

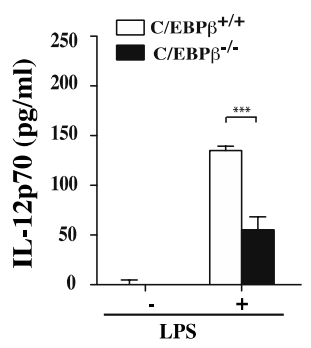

G

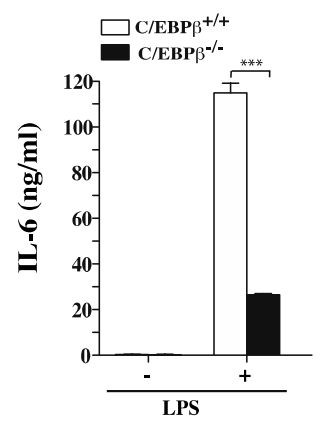

Figure 6. Effect of C/EBP $\beta$ deficiency on gene expression and production of IL-10 and IL-12 by GM/DCs. Bone marrow-derived GM/DCs generated from C/EBP $\beta^{-/-}$or $\mathrm{C} / \mathrm{EBP} \beta^{+/+}$mice were left unstimulated or were stimulated with $1 \mu \mathrm{g} / \mathrm{mL}$ of LPS for $4 \mathrm{~h}$ and $12 \mathrm{~h}$. The expression of IL-10 (A), IL12p35 (B), IL-12p40 (C), and IL-6 (D) was determined by real-time PCR. Data are shown as fold increases with reference to unstimulated GM/DCs of $\mathrm{C} / \mathrm{EBP} \beta^{+/+}(t=0)$ and are representative of four independent experiments. For cytokines release, bone marrow-derived GM/DCs generated from $\mathrm{C} / \mathrm{EBP} \beta^{-/-}$or $\mathrm{C} / \mathrm{EBP} \beta^{+/+}$mice were left unstimulated or stimulated with LPS $(1 \mu \mathrm{g} / \mathrm{mL}$ for $24 \mathrm{~h}$ ). Cell supernatants were collected and IL-10 (E), IL-12p70 (F), and IL-6 (G) production was analyzed by ELISA. Data are representative of three independent experiments and are shown as the mean \pm SEM. The asterisks $\left(^{*}\right)$ correspond to $p<0.01\left(^{* *}\right)$ and $p<0.001(* *)$, one-way ANOVA with post hoc Bonferroni's test. 

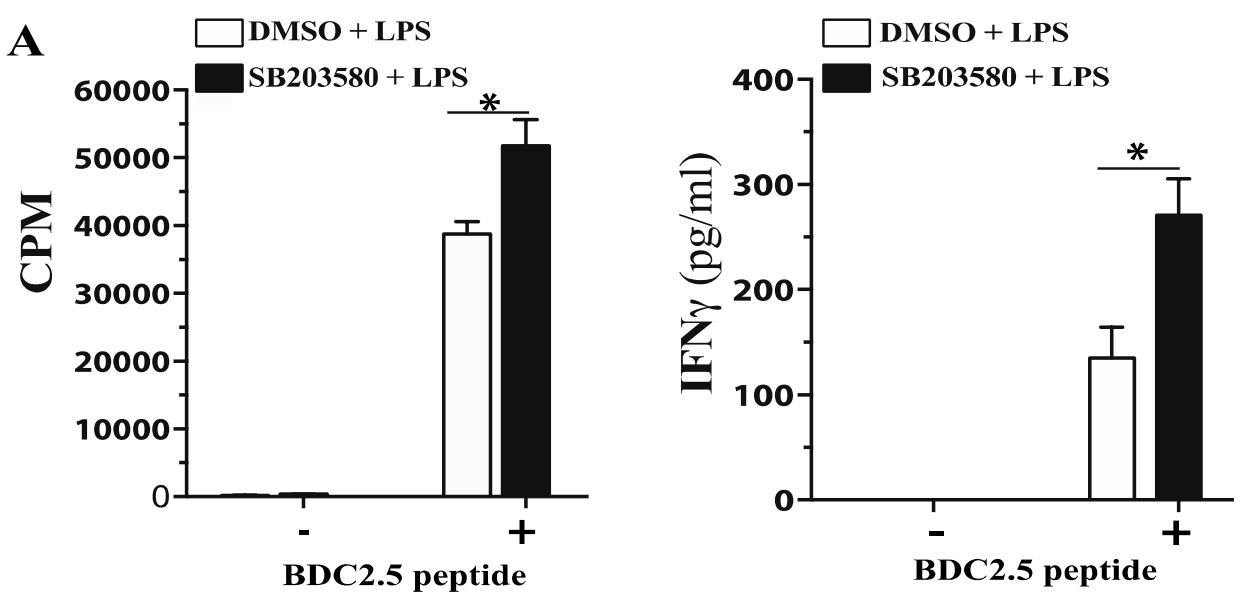

B
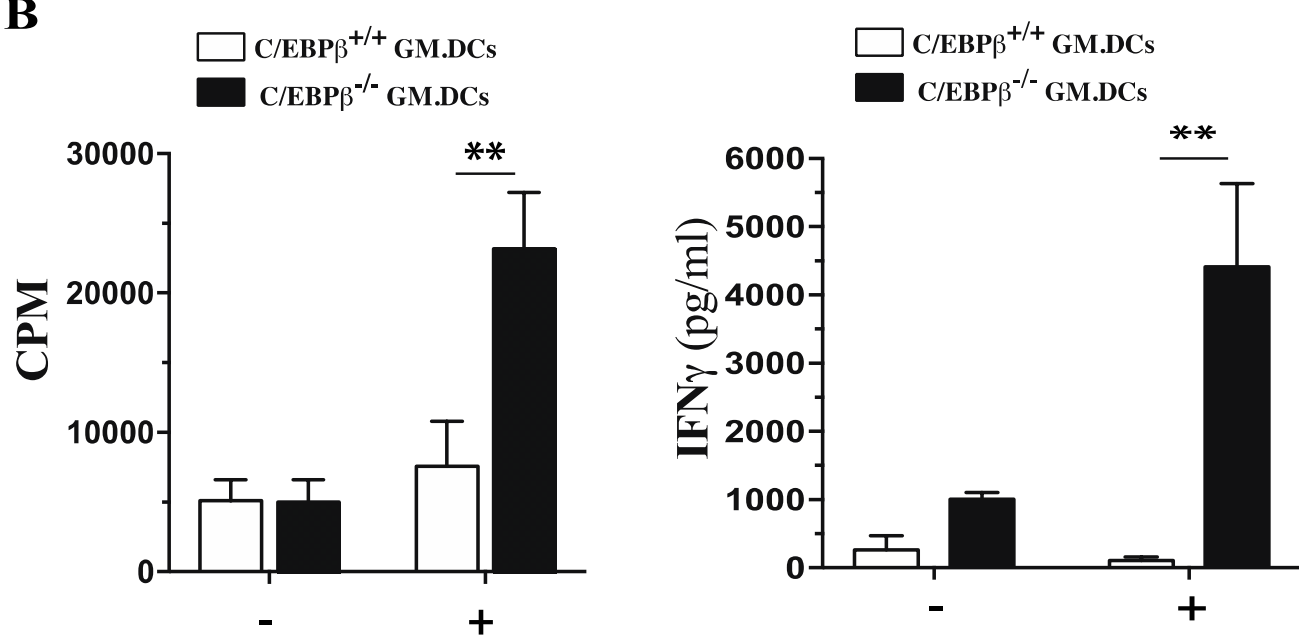

Figure 7. Elevated $\mathrm{CD}^{+} \mathrm{T}$ cell proliferation and IFN $\gamma$ production induced by the p38 MAPK inhibitor-treated or C/EBP $\beta$-deficient GM/DCs. (A) Proliferative response and IFN $\gamma$ secretion by autoreactive BDC2.5-CD4 ${ }^{+}$T cells that had been cultured with GM/DCs treated with p38 MAPK inhibitor SB203580 or with vehicle (DMSO) and pulsed or not with BDC2.5-peptide. (B) Proliferative response and IFN $\gamma$ secretion by naïve $\mathrm{CD}^{+} \mathrm{T}$ cells purified from $\mathrm{C} / \mathrm{EBP} \beta^{+/+}$littermate control mice that have been activated with anti-CD3 and anti-CD28 Abs in the presence of $\mathrm{C} / \mathrm{EBP} \beta^{+/+}$or $\mathrm{C} / \mathrm{EBP} \beta^{-/-} \mathrm{GM} / \mathrm{DC}$ s before (-) and after (+) LPS stimulation. Quantification of IFN $\gamma$ released in the supernatant. Data are representative of three independent experiments and are shown as the mean \pm SD. The asterisks $\left(^{*}\right)$ correspond to $\left.p<0.01{ }^{* *}\right)$, one-way ANOVA with post hoc Bonferroni's test.

\section{Discussion}

We have previously reported that in vitro bone marrow-derived GM/DCs exhibit a signature of tolerogenic semi-mature IL-10-producing DCs whereas IL-4/DCs exhibit the functional properties and phenotype of fully mature immunogenic IL-12-producing DCs [8]. We have also reported that inhibition of the MEK1/2-AP-1 pathway reduced production of IL-10 and enhanced production of IL-12p70 but had no effect on the phenotype of semi-mature GM/DCs [8]. The transcription factor C/EBP $\beta$ has been extensively studied with respect to regulation of IL-10/IL-12 balance in macrophages, but its role in phenotype and function of tolerogenic DC remains to be elucidated. Results reported here showed that semi-mature phenotype and IL-10/IL12 production by tolerogenic GM/DCs were under the control of the p38 MAPK-C/EBP $\beta$ axis and that the expression of C/EBP $\beta$ was necessary to maintain low levels of expression of CD80/CD86 and high production of IL-10 by tolerogenic $\mathrm{GM} / \mathrm{DC}$ s as well as their reduced capacity to induce $\mathrm{CD} 4^{+} \mathrm{T}$ cells proliferation and IFN $\gamma$ production. 
DCs coordinate immune response because they play a critical role in induction of immunity and triggering $\mathrm{T}$ cell tolerance. It is well established that the maturation stage and nature of cytokines produced by DCs are important determinants of their tolerogenic as opposed to their immunogenic functions. Fully matured DCs potently induce effector $\mathrm{T}$ cell responses because of an increased expression of costimulatory molecules such as CD80 and CD86 and pro-inflammatory cytokines. In contrast, low or intermediate expression of maturation markers as well as IL-10 secretion are the characteristics of tolerogenic DCs that are important events in the induction and maintenance of immune tolerance. Of interest, DCs play a critical role in the initiation and progression of autoimmune diseases including type 1 diabetes. We and others have shown that BMDCs generated from NOD mice display a more mature phenotype, produce more proinflammatory cytokines (such IL-12p70) but less anti-inflammatory cytokines (such IL-10) and promote pro-inflammatory immune response [8,51,52]. We have also reported that splenic DCs purified from GM-CSF-treated NOD mice as well as bone marrow-derived GM/DCs exhibit similar properties of semi-mature tolerogenic DCs [6,8]. However, the molecular mechanisms that govern tolerogenic properties of these DCs are not fully understood. Data presented here showed that C/EBP $\beta$ was highly activated in tolerogenic GM/DCs following LPS stimulation but not in immunogenic IL-4/DCs. Furthermore, phosphorylated C/EBP $\beta$ exhibited strong DNA binding activity in IL-10-producing GM/DCs but not in IL-12p70 producing IL-4/DCs. These data clearly indicated that C/EBP $\beta$ expression and DNA binding activity are involved in regulating immune-regulatory genes of tolerogenic GM/DCs.

C/EBP $\beta$ requires the phosphorylation of two residues for its optimal transcriptional activity $[40,48,53]$. Its phosphorylation of Thr188 is mediated by $\mathrm{p} 38$ MAPK or by ERK1/2, depending on cell type [48]. We found that p38 MAPK was involved in phosphorylation of Thr188 in GM/DCs, which also entailed an increased DNA binding activity. The drastic reductions of C/EBP $\beta$ phosphorylation and its DNA binding activity in the presence of the p38MAPK inhibitor correlated with a decrease in CREB DNA binding activity, which is known to regulate $C / E B P \beta$ expression [54]. The other phosphorylation sites of C/EBP $\beta$ are mediated by GSK3 at residues Thr179 and Ser184. These covalent modifications allow $C / E B P \beta$ to undergo conformational changes needed to bind DNA $[40,48]$. GSK3 is known to phosphorylate several other transcription factors such as CREB and AP-1, which regulate IL-10 gene expression [55,56]. In agreement with these reports, we found a robust phosphorylation of CREB at Ser129 and Ser133 in GM/DCs but not in IL-4/DCs, indicating high GSK3 activity in tolerogenic GM/DCs. In immunogenic IL-4/DCs, CREB phosphorylation at Ser129 was less important, suggesting lower GSK3 activity in these cells. The low levels of CREB phosphorylation of Ser129 in IL-4/DCs could be attributed to the fact that IL-4 is an important activator of the PI3K/Akt pathway [57], which is responsible for phosphorylation and inactivation of GSK3 [58].

We have previously reported that MEK1/2 inhibition in GM/DCs resulted in inhibition of AP-1 DNA binding activity and a 50\% decrease of IL-10 production. These observations suggested that other pathways were involved in regulating IL-10 production in GM/DCs [8]. GSK3 has been reported to play a central role in determining the nature and magnitude of pro- versus anti-inflammatory cytokine production [39,59]. Our data showed that the inhibition of GSK3 activity increased IL-10 secretion whereas IL-12 production was significantly reduced in LPS-stimulated GM/DCs. These results are in agreement with previous studies that reported that GSK3 inhibition triggered increases in IL-10 production but decreases in IL-12 production by human monocytes, DCs and macrophages in response to TLR agonists [39,59-61]. Similarly, it has been reported that GSK3 inhibition increased CREB DNA binding activity that resulted in suppression of pro-inflammatory cytokines production but increased IL-10 secretion. These combined effects favored protection of mice from endotoxin shock [39]. Inhibition of GSK3 in monocyte-derived DCs resulted in an increased surface expression of costimulatory molecules [62,63]. In agreement with these reports, our results showed that GSK3 inhibition led to increased levels of expression of CD80 and CD86 in the case of LPS stimulated GM/DCs whereas inhibition of p38 MAPK activity had a minor effect on LPS-stimulated GM/DCs maturation status. These observations could be attributed to low levels of costimulatory molecules 
expressed on semi-mature GM/DCs. In addition, other groups have shown that RelB was involved in expression of costimulatory molecules in DCs $[64,65]$. It has been reported that CREB was essential for expression of CD80, CD83, and CD86 in human monocyte-derived DCs [66]. In this respect, we found that GSK3 inhibition in GM/DCs had no effect on CREB DNA binding activity but significantly reduced DNA binding of C/EBP $\beta$. These observations suggested the involvement of GSK3 $\beta-C / E B P \beta$ in regulating phenotype and IL-10/IL-12 production by GM/DCs.

Classical C/EBP binding sites are present in many cytokine promoters such as those of IL-12p40, GM-CSF and IL-6 genes whereas CREB regulates the expression of genes such as IL-10. We found that inhibition of p38 MAPK in GM/DCs led to a drastic reduction in both CREB and C/EBP $\beta$ DNA binding activities, as well as a loss of IL-10 production. These findings suggest that inhibition of p38 MAPK was likely to target both C/EBP $\beta$ and CREB factors, and the latter is also known to control IL-10 production. Therefore, the presence of residual IL-10 is not unexpected in C/EBP $\beta^{-/-}$ GM/DCs, as CREB would remain unaffected (as would other transcription factors). However, p38 MAPK inhibition led to an increased production of IL-12p70 that was comparable to that of IL-4/DCs. Our data are in line with the report that showed that C5aR inhibited the pro-inflammatory potential of a very pro-inflammatory human DC subset (slanDCs) and induced IL-10 production by initiating and prolonging ERK and p38 MAPK phosphorylation as well as CREB phosphorylation [67]. Furthermore, inhibition of ERK1/2 or 338 MAPK phosphorylation or inhibition of signal transduction upstream of CREB1 (via MSK1/2 inhibition) abrogated the ability of C5aR to induce IL-10 gene expression in LPS-stimulated moDCs. Another report has shown that the p38 MAPK-CREB axis mediated IL-10 secretion in TLR2 and PSM-treated DCs and that resulted in enhanced activation of p38 MAPK-CREB-IL-10 axis. Of significance, this response was prevented by inhibition of p38 MAPK, suggesting the involvement of the p38 MAPK-CREB axis in IL-10 production induced by PSMa3 [68].

Our study showed, to the best of our knowledge, for the first time that C/EBP $\beta$ was responsible for the low expression of the costimulatory molecules in tolerogenic GM/DCs. This observation was corroborated by increased expression of costimulatory molecules in GM/DCs generated from $\mathrm{C} / \mathrm{EBP} \beta^{-/-}$mice. We have previously reported that GM/DCs expressed low levels of CD80 and CD86 but high levels of PDL-1. They also produced high amounts of IL-10 while reducing their ability to activate autoreactive T cells. These GM/DCs induced Treg differentiation, suggesting that these cells possess the signature of tolerogenic DCs $[7,8]$. Here, we found high levels of expression and strong DNA binding activity of C/EBP $\beta$ in tolerogenic GM/DCs as compared to immunogenic IL-4/DCs. Our findings were in agreement with the report that showed that tumors induced tolerogenic and immunosuppressive MDSCs, and that the tumor-derived soluble factor GM-CSF controlled this immunosuppression in a C/EBP $\beta$-dependent manner [69]. Since in our bone marrow derived DCs, $90 \%$ of non-adherent cells expressed moderate to high levels of CD11c/MHC-Class II and less than $10 \%$ were Gr1 positive, we do not exclude the possibility that the deletion of C/EBP $\beta$ in myeloid cell subpopulations may also contribute to IL-10/IL-12p70 regulation. In addition, a recent study has shown that the lymphoma-promoting tolerogenic function of IL-10 produced by DCs was regulated by the C/EBP $\beta$ transcription factor [50]. This study further showed that, C/EBP $\beta$ controlled-lymphoma-associated C/EBP $\beta$ competent DCs expressed high levels of IL-10 and IL-6. In contrast, lymphoma-associated C/EBP $\beta$-deficient DCs produced less amounts of these cytokines [50]. To explore the function of C/EBP $\beta$ in GM/DCs, we focused on genes that were informative for immunoregulatory as opposed to inflammatory function. We selected IL-10, IL-6, and IL-12 cytokines and costimulatory molecules as targets of our investigations. Interestingly, we found lower levels of expression of IL-10 mRNA and reduced secretion after a $24 \mathrm{~h}$ stimulation with LPS in GM/DCs of $\mathrm{C} / \mathrm{EBP} \beta^{-/-}$mice compared to $\mathrm{C} / \mathrm{EBP} \beta^{+/+}$mice. These observations suggested that $C / E B P \beta$ was also necessary for gene expression and production of IL-10. In the context of autoimmune diabetes, pDCs have been shown to be essential to initiate the development of the disease whereas $\mathrm{pDC}$ depletion induced diabetes protection $[70,71]$. We have previously have reported that conventional tolerogenic DCs are major contributors to diabetes resistance [72]. Of interest, pDCs 
were drastically diminished in diabetes-resistant mice and their conventional DCs express low level of IRF8 as compared to DCs of diabetic mice (Zerif E. et al. unpublished data). It is therefore tempting to hypothesize that tolerogenic DCs function in diabetes-resistant mice express high levels of active $\mathrm{C} / \mathrm{EBP} \beta$ as we observed in the case of tolerogenic GM/DCs as compared to IL-4/DCs. C/EBP $\beta$ phosphorylation and DNA binding in conventional DCs of diabetes-resistant NOD mice and diabetic NOD mice is currently under investigation in our laboratory.

Data reported here led us to conclude that C/EBP $\beta$ was critical for production of IL-12 and IL-6 since their production was drastically reduced in $\mathrm{C} / \mathrm{EBP} \beta^{-/-} \mathrm{GM} / \mathrm{DC}$. In this connection, previous reports have shown that IL-6 production was not affected in activated C/EBP ${ }^{-/-}$macrophages and that $C / E B P \beta$ compensated the lack of C/EBP $\beta$ for IL-6 production [30,31]. Since LPS-stimulated GM/DCs produced IL-6 in the absence of C/EBP $\beta$ DNA binding activity, this finding suggested that the inhibition of IL-6 production observed in C/EBP $\beta^{-/-}$GM/DCs was not compensated by other $\mathrm{C} / \mathrm{EBP}$ isoforms. However, our data do not exclude the possibility that C/EBP is not involved in IL-6 production by tolerogenic DCs. Importantly, we found that inhibition of p38 MAPK in GM/DCs or $\mathrm{C} / \mathrm{EBP} \beta^{-/-} \mathrm{GM} / \mathrm{DC}$ s have greater capacity to induce $\mathrm{CD} 4^{+} \mathrm{T}$ cells proliferation and enhanced IFN $\gamma$ production. High production of IFN $\gamma$ by $\mathrm{CD}^{+}{ }^{+} \mathrm{T}$ cells could be the results of marked reduction of IL-10 and IL-6 produced by C/EBP $\beta^{-/-}$GM/DCs. Indeed, IL-10 and IL- 6 have been reported to be limiting factors for Th1 development response even in the presence of IL-12 [73-75]. Our findings are also supported by a study that used adoptively transferred OT-II CD4 ${ }^{+} \mathrm{T}$ cells into tumor-bearing mice that showed that lymphoma-educated C/EBP $\beta$ competent DCs reduced OT-II CD4 ${ }^{+} \mathrm{T}$ cell proliferation and that inhibition of OT-II T cell proliferation was reverted in the presence of $\mathrm{C} / \mathrm{EBP} \beta^{-/-} \mathrm{DCs}$ [50]. Furthermore, it has been reported that $\mathrm{C} / \mathrm{EBP} \beta$ plays an essential role in limiting immunosuppressive function such as inhibiting $\mathrm{T}$ cell proliferation and IFN $\gamma$ production [49]. These authors found that $\mathrm{C} / \mathrm{EBP} \beta^{-/-}$MDSC cells produce less IL-10 and induce a strong $\mathrm{CD} 4^{+} \mathrm{T}$ cell proliferation and IFN $\gamma$ production, whereas $\mathrm{C} / \mathrm{EBP} \beta$ overexpression repress $\mathrm{CD} 4^{+} \mathrm{T}$ cell proliferation and activation, as well as their IFN $\gamma$ production. Data reported here clearly highlight the fact that $\mathrm{C} / \mathrm{EBP} \beta$ is a key transcription factor that governs tolerogenic phenotype and function of GM/DCs, which is critical in tolerance induction within the context of autoimmunity.

\section{Conclusions}

In conclusion, our study has shown that $C / E B P \beta$ is a master regulator of tolerogenic DCs function and has identified a critical role for the $\mathrm{p} 38$ MAPK-C/EBP $\beta$ pathway in the regulation of IL-10 and IL-12p70 production, as well as the maturation status of bone marrow-derived tolerogenic semi-mature GM/DCs. In particular, we have identified key signaling molecules involved in the regulation of important features of tolerogenic DCs, namely p38 MAPK and GSK3. Clinical implications may emerge from these observations such as targeting pathways that lead to C/EBP $\beta$ activation in DCs. This experimental approach could help to improve tolerogenic DCs function and may be used as a basis to design efficient therapy to prevent autoimmune diseases such as type I diabetes.

Supplementary Materials: The following are available online at http:/ /www.mdpi.com/2073-4409/7/12/256/s1, Figure S1: Cellular localization of C/EBP $\beta$ in GM/DCs and IL-4/DCs, Figure S2: Effect of GSK3 inhibitor (LiCl) on IL-10 and IL-12p70 production by GM/DCs, Table S1: Sequences of the primers used for real time PCR analysis.

Author Contributions: A.A., C.G., and P.P.M. designed the study and the experiments; C.G., A.C., E.Z., and O.T. performed the experiments, statistical analysis. C.G. and A.A. wrote the manuscript. C.G. and C.A. helped with genotyping the C/EBP $\beta$ deficient mice. G.D., D.G., P.P.M., and A.A. contributed to the conceptual reading and critical editing of the manuscript.

Funding: This work was supported by grant to AA from CIHR (MOP-300762) and the National Sciences and Engineering Research Council of Canada (NSERC) (RGPIN-2015-03671); and to PPM from CIHR (MOP 89760).

Acknowledgments: We would like to thank Peter F. Johnson (National Cancer Institute, Frederick, MD, USA) for providing $\mathrm{C} / \mathrm{EBP} \beta$-deficient mice and Isabelle Marois for her excellent assistance in Flow cytometry analysis.

Conflicts of Interest: The authors declare no conflict of interest. 


\section{References}

1. Van Vliet, S.J.; den Dunnen, J.; Gringhuis, S.I.; Geijtenbeek, T.B.; van Kooyk, Y. Innate signaling and regulation of dendritic cell immunity. Curr. Opin. Immunol. 2007, 19, 435-440. [CrossRef] [PubMed]

2. Banchereau, J.; Steinman, R.M. Dendritic cells and the control of immunity. Nature 1998, 392, $245-252$. [CrossRef] [PubMed]

3. Steinman, R.M.; Hawiger, D.; Nussenzweig, M.C. Tolerogenic dendritic cells. Annu. Rev. Immunol. 2003, 21, 685-711. [CrossRef] [PubMed]

4. McColl, S.R. Chemokines and dendritic cells: A crucial alliance. Immunol. Cell Biol. 2002, 80, 489-496. [CrossRef] [PubMed]

5. Besin, G.; Gaudreau, S.; Menard, M.; Guindi, C.; Dupuis, G.; Amrani, A. Thymic stromal lymphopoietin and thymic stromal lymphopoietin-conditioned dendritic cells induce regulatory T-cell differentiation and protection of NOD mice against diabetes. Diabetes 2008, 57, 2107-2117. [CrossRef] [PubMed]

6. Gaudreau, S.; Guindi, C.; Menard, M.; Besin, G.; Dupuis, G.; Amrani, A. Granulocyte-macrophage colony-stimulating factor prevents diabetes development in nod mice by inducing tolerogenic dendritic cells that sustain the suppressive function of CD4+CD25+ regulatory T cells. J. Immunol. 2007, 179, 3638-3647. [CrossRef] [PubMed]

7. Gaudreau, S.; Guindi, C.; Menard, M.; Benabdallah, A.; Dupuis, G.; Amrani, A. GM-CSF induces bone marrow precursors of NOD mice to skew into tolerogenic dendritic cells that protect against diabetes. Cell Immunol. 2010, 265, 31-36. [CrossRef] [PubMed]

8. Guindi, C.; Menard, M.; Cloutier, A.; Gaudreau, S.; Besin, G.; Larivee, P.; McDonald, P.P.; Dupuis, G.; Amrani, A. Differential role of NF-kappaB, ERK1/2 and AP-1 in modulating the immunoregulatory functions of bone marrow-derived dendritic cells from nod mice. Cell. Immunol. 2012, 272, 259-268. [CrossRef] [PubMed]

9. Lutz, M.B.; Schuler, G. Immature, semi-mature and fully mature dendritic cells: Which signals induce tolerance or immunity? Trends Immunol. 2002, 23, 445-449. [CrossRef]

10. Rutella, S.; Bonanno, G.; Pierelli, L.; Mariotti, A.; Capoluongo, E.; Contemi, A.M.; Ameglio, F.; Curti, A.; De Ritis, D.G.; Voso, M.T.; et al. Granulocyte colony-stimulating factor promotes the generation of regulatory dc through induction of IL-10 and IFN-Alpha. Eur. J. Immunol. 2004, 34, 1291-1302. [CrossRef] [PubMed]

11. Chorny, A.; Gonzalez-Rey, E.; Fernandez-Martin, A.; Pozo, D.; Ganea, D.; Delgado, M. Vasoactive intestinal peptide induces regulatory dendritic cells with therapeutic effects on autoimmune disorders. Proc. Natl. Acad. Sci. USA 2005, 102, 13562-13567. [CrossRef] [PubMed]

12. Ganesh, B.B.; Cheatem, D.M.; Sheng, J.R.; Vasu, C.; Prabhakar, B.S. GM-CSF-induced CD11C+CD8A-Dendritic cells facilitate FOXP3+ and IL-10+ regulatory T cell expansion resulting in suppression of autoimmune thyroiditis. Int. Immunol. 2009, 21, 269-282. [CrossRef] [PubMed]

13. Burkly, L.; Hession, C.; Ogata, L.; Reilly, C.; Marconi, L.A.; Olson, D.; Tizard, R.; Cate, R.; Lo, D. Expression of relb is required for the development of thymic medulla and dendritic cells. Nature 1995, 373, 531-536. [CrossRef] [PubMed]

14. Ouaaz, F.; Arron, J.; Zheng, Y.; Choi, Y.; Beg, A.A. Dendritic cell development and survival require distinct NF-kappaB subunits. Immunity 2002, 16, 257-270. [CrossRef]

15. Rescigno, M.; Martino, M.; Sutherland, C.L.; Gold, M.R.; Ricciardi-Castagnoli, P. Dendritic cell survival and maturation are regulated by different signaling pathways. J. Exp. Med. 1998, 188, 2175-2180. [CrossRef] [PubMed]

16. Wu, L.; D'Amico, A.; Winkel, K.D.; Suter, M.; Lo, D.; Shortman, K. Relb is essential for the development of myeloid-related CD8alpha- dendritic cells but not of lymphoid-related CD8alpha+ dendritic cells. Immunity 1998, 9, 839-847. [CrossRef]

17. Loscher, C.E.; Draper, E.; Leavy, O.; Kelleher, D.; Mills, K.H.; Roche, H.M. Conjugated linoleic acid suppresses NF-kappaB activation and IL-12 production in dendritic cells through ERK-mediated IL-10 induction. J. Immunol. 2005, 175, 4990-4998. [CrossRef] [PubMed]

18. Puig-Kroger, A.; Relloso, M.; Fernandez-Capetillo, O.; Zubiaga, A.; Silva, A.; Bernabeu, C.; Corbi, A.L. Extracellular signal-regulated protein kinase signaling pathway negatively regulates the phenotypic and functional maturation of monocyte-derived human dendritic cells. Blood 2001, 98, 2175-2182. [CrossRef] [PubMed] 
19. Huang, Q.; Liu, D.; Majewski, P.; Schulte, L.C.; Korn, J.M.; Young, R.A.; Lander, E.S.; Hacohen, N. The plasticity of dendritic cell responses to pathogens and their components. Science 2001, 294, 870-875. [CrossRef]

20. Langenkamp, A.; Messi, M.; Lanzavecchia, A.; Sallusto, F. Kinetics of dendritic cell activation: Impact on priming of Th1, Th2 and nonpolarized T cells. Nat. Immunol. 2000, 1, 311-316. [CrossRef]

21. Yi, A.K.; Yoon, J.G.; Yeo, S.J.; Hong, S.C.; English, B.K.; Krieg, A.M. Role of mitogen-activated protein kinases in CPG DNA-mediated IL-10 and IL-12 production: Central role of extracellular signal-regulated kinase in the negative feedback loop of the CPG DNA-mediated Th1 response. J. Immunol. 2002, 168, 4711-4720. [CrossRef] [PubMed]

22. Dillon, S.; Agrawal, A.; Van Dyke, T.; Landreth, G.; McCauley, L.; Koh, A.; Maliszewski, C.; Akira, S.; Pulendran, B. A toll-like receptor 2 ligand stimulates Th2 responses in vivo, via induction of extracellular signal-regulated kinase mitogen-activated protein kinase and C-FOS in dendritic cells. J. Immunol. 2004, 172, 4733-4743. [CrossRef] [PubMed]

23. Escors, D.; Lopes, L.; Lin, R.; Hiscott, J.; Akira, S.; Davis, R.J.; Collins, M.K. Targeting dendritic cell signaling to regulate the response to immunization. Blood 2008, 111, 3050-3061. [CrossRef] [PubMed]

24. Agrawal, A.; Dillon, S.; Denning, T.L.; Pulendran, B. ERK1-/- mice exhibit th1 cell polarization and increased susceptibility to experimental autoimmune encephalomyelitis. J. Immunol. 2006, 176, 5788-5796. [CrossRef] [PubMed]

25. Poli, V. The role of C/EBP isoforms in the control of inflammatory and native immunity functions. J. Biol. Chem. 1998, 273, 29279-29282. [CrossRef] [PubMed]

26. Ramji, D.P.; Foka, P. Ccaat/enhancer-binding proteins: Structure, function and regulation. Biochem. J. 2002, 365, 561-575. [CrossRef] [PubMed]

27. Brenner, S.; Prosch, S.; Schenke-Layland, K.; Riese, U.; Gausmann, U.; Platzer, C. Camp-induced interleukin-10 promoter activation depends on ccaat/enhancer-binding protein expression and monocytic differentiation. J. Biol. Chem. 2003, 278, 5597-5604. [CrossRef] [PubMed]

28. Liu, Y.W.; Tseng, H.P.; Chen, L.C.; Chen, B.K.; Chang, W.C. Functional cooperation of simian virus 40 promoter factor 1 and ccaat/enhancer-binding protein beta and delta in lipopolysaccharide-induced gene activation of IL-10 in mouse macrophages. J. Immunol. 2003, 171, 821-828. [CrossRef] [PubMed]

29. Gorgoni, B.; Maritano, D.; Marthyn, P.; Righi, M.; Poli, V. C/EBP beta gene inactivation causes both impaired and enhanced gene expression and inverse regulation of IL-12 p40 and p35 mrnas in macrophages. J. Immunol. 2002, 168, 4055-4062. [CrossRef]

30. Screpanti, I.; Romani, L.; Musiani, P.; Modesti, A.; Fattori, E.; Lazzaro, D.; Sellitto, C.; Scarpa, S.; Bellavia, D.; Lattanzio, G.; et al. Lymphoproliferative disorder and imbalanced T-helper response in C/EBP beta-deficient mice. Embo J. 1995, 14, 1932-1941. [CrossRef]

31. Tanaka, T.; Akira, S.; Yoshida, K.; Umemoto, M.; Yoneda, Y.; Shirafuji, N.; Fujiwara, H.; Suematsu, S.; Yoshida, N.; Kishimoto, T. Targeted disruption of the NF-IL6 gene discloses its essential role in bacteria killing and tumor cytotoxicity by macrophages. Cell 1995, 80, 353-361. [CrossRef]

32. Bradley, M.N.; Zhou, L.; Smale, S.T. C/EBPbeta regulation in lipopolysaccharide-stimulated macrophages. Mol. Cell. Biol. 2003, 23, 4841-4858. [CrossRef] [PubMed]

33. Boyle, W.J.; Smeal, T.; Defize, L.H.; Angel, P.; Woodgett, J.R.; Karin, M.; Hunter, T. Activation of protein kinase c decreases phosphorylation of C-JUN at sites that negatively regulate its DNA-binding activity. Cell 1991, 64, 573-584. [CrossRef]

34. Bullock, B.P.; Habener, J.F. Phosphorylation of the camp response element binding protein creb by camp-dependent protein kinase a and glycogen synthase kinase-3 alters DNA-binding affinity, conformation, and increases net charge. Biochemistry 1998, 37, 3795-3809. [CrossRef] [PubMed]

35. Fiol, C.J.; Williams, J.S.; Chou, C.H.; Wang, Q.M.; Roach, P.J.; Andrisani, O.M. A secondary phosphorylation of CREB341 at SER129 is required for the camp-mediated control of gene expression. A role for glycogen synthase kinase-3 in the control of gene expression. J. Biol. Chem. 1994, 269, 32187-32193.

36. Grimes, C.A.; Jope, R.S. Creb DNA binding activity is inhibited by glycogen synthase kinase-3 beta and facilitated by lithium. J. Neurochem. 2001, 78, 1219-1232. [CrossRef]

37. Ruffell, D.; Mourkioti, F.; Gambardella, A.; Kirstetter, P.; Lopez, R.G.; Rosenthal, N.; Nerlov, C. A creb-C/EBPbeta cascade induces $\mathrm{m} 2$ macrophage-specific gene expression and promotes muscle injury repair. Proc. Natl. Acad. Sci. USA 2009, 106, 17475-17480. [CrossRef] 
38. Park, J.M.; Greten, F.R.; Wong, A.; Westrick, R.J.; Arthur, J.S.; Otsu, K.; Hoffmann, A.; Montminy, M.; Karin, M. Signaling pathways and genes that inhibit pathogen-induced macrophage apoptosis-creb and NF-kappaB as key regulators. Immunity 2005, 23, 319-329. [CrossRef] [PubMed]

39. Martin, M.; Rehani, K.; Jope, R.S.; Michalek, S.M. Toll-like receptor-mediated cytokine production is differentially regulated by glycogen synthase kinase 3. Nat. Immunol. 2005, 6, 777-784. [CrossRef]

40. Kim, J.W.; Tang, Q.Q.; Li, X.; Lane, M.D. Effect of phosphorylation and s-s bond-induced dimerization on DNA binding and transcriptional activation by C/EBPbeta. Proc. Natl. Acad. Sci. USA 2007, 104, 1800-1804. [CrossRef]

41. Lobo, P.I.; Schlegel, K.H.; Bajwa, A.; Huang, L.; Okusa, M.D. Natural igm and tlr agonists switch murine splenic pan-b to "regulatory" cells that suppress ischemia-induced innate inflammation via regulating NKT-1 cells. Front. Immunol. 2017, 8, 974. [CrossRef] [PubMed]

42. Cloutier, A.; Guindi, C.; Larivee, P.; Dubois, C.M.; Amrani, A.; McDonald, P.P. Inflammatory cytokine production by human neutrophils involves C/EBP transcription factors. J. Immunol. 2009, 182, 563-571. [CrossRef] [PubMed]

43. Csoka, B.; Nemeth, Z.H.; Virag, L.; Gergely, P.; Leibovich, S.J.; Pacher, P.; Sun, C.X.; Blackburn, M.R.; Vizi, E.S.; Deitch, E.A.; et al. A2a adenosine receptors and C/EBPbeta are crucially required for IL-10 production by macrophages exposed to Escherichia coli. Blood 2007, 110, 2685-2695. [CrossRef] [PubMed]

44. Sato, K.; Yamashita, N.; Matsuyama, T. Human peripheral blood monocyte-derived interleukin-10-induced semi-mature dendritic cells induce anergic CD4(+) and CD8(+) T cells via presentation of the internalized soluble antigen and cross-presentation of the phagocytosed necrotic cellular fragments. Cell. Immunol. 2002, 215, 186-194. [CrossRef]

45. Steinbrink, K.; Graulich, E.; Kubsch, S.; Knop, J.; Enk, A.H. CD4(+) and CD8(+) anergic t cells induced by interleukin-10-treated human dendritic cells display antigen-specific suppressor activity. Blood 2002, 99, 2468-2476. [CrossRef] [PubMed]

46. Steinbrink, K.; Wolfl, M.; Jonuleit, H.; Knop, J.; Enk, A.H. Induction of tolerance by IL-10-treated dendritic cells. J. Immunol. 1997, 159, 4772-4780. [PubMed]

47. Wakkach, A.; Fournier, N.; Brun, V.; Breittmayer, J.P.; Cottrez, F.; Groux, H. Characterization of dendritic cells that induce tolerance and T regulatory 1 cell differentiation in vivo. Immunity 2003, 18, 605-617. [CrossRef]

48. Tang, Q.Q.; Gronborg, M.; Huang, H.; Kim, J.W.; Otto, T.C.; Pandey, A.; Lane, M.D. Sequential phosphorylation of ccaat enhancer-binding protein beta by mapk and glycogen synthase kinase 3beta is required for adipogenesis. Proc. Natl. Acad. Sci. USA 2005, 102, 9766-9771. [CrossRef]

49. Dai, J.; Kumbhare, A.; Youssef, D.; Yao, Z.Q.; McCall, C.E.; El Gazzar, M. Expression of C/EBPbeta in myeloid progenitors during sepsis promotes immunosuppression. Mol. Immunol. 2017, 91, 165-172. [CrossRef]

50. Rehm, A.; Gatjen, M.; Gerlach, K.; Scholz, F.; Mensen, A.; Gloger, M.; Heinig, K.; Lamprecht, B.; Mathas, S.; Begay, V.; et al. Dendritic cell-mediated survival signals in EMU-MYC B-cell lymphoma depend on the transcription factor C/EBPbeta. Nat. Commun. 2014, 5, 5057. [CrossRef]

51. Poligone, B.; Weaver, D.J., Jr.; Sen, P.; Baldwin, A.S., Jr.; Tisch, R. Elevated NF-kappab activation in nonobese diabetic mouse dendritic cells results in enhanced apc function. J. Immunol. 2002, 168, 188-196. [CrossRef] [PubMed]

52. Feili-Hariri, M.; Morel, P.A. Phenotypic and functional characteristics of BM-derived DC from NOD and non-diabetes-prone strains. Clin. Immunol. 2001, 98, 133-142. [CrossRef] [PubMed]

53. Piwien-Pilipuk, G.; MacDougald, O.; Schwartz, J. Dual regulation of phosphorylation and dephosphorylation of C/EBPbeta modulate its transcriptional activation and DNA binding in response to growth hormone. J. Biol. Chem. 2002, 277, 44557-44565. [CrossRef] [PubMed]

54. Niehof, M.; Manns, M.P.; Trautwein, C. Creb controls LAP/C/EBP beta transcription. Mol. Cell. Biol. 1997, 17, 3600-3613. [CrossRef] [PubMed]

55. Gotschel, F.; Kern, C.; Lang, S.; Sparna, T.; Markmann, C.; Schwager, J.; McNelly, S.; von Weizsacker, F.; Laufer, S.; Hecht, A.; et al. Inhibition of GSK3 differentially modulates NF-kappaB, creb, AP-1 and beta-catenin signaling in hepatocytes, but fails to promote TNF-alpha-induced apoptosis. Exp. Cell Res. 2008, 314, 1351-1366. [CrossRef] [PubMed]

56. Beurel, E.; Jope, R.S. Differential regulation of stat family members by glycogen synthase kinase-3. J. Biol. Chem. 2008, 283, 21934-21944. [CrossRef] [PubMed] 
57. Harris, J.; De Haro, S.A.; Master, S.S.; Keane, J.; Roberts, E.A.; Delgado, M.; Deretic, V. T helper 2 cytokines inhibit autophagic control of intracellular mycobacterium tuberculosis. Immunity 2007, 27, 505-517. [CrossRef] [PubMed]

58. Cross, D.A.; Alessi, D.R.; Cohen, P.; Andjelkovich, M.; Hemmings, B.A. Inhibition of glycogen synthase kinase-3 by insulin mediated by protein kinase B. Nature 1995, 378, 785-789. [CrossRef] [PubMed]

59. Hu, X.; Paik, P.K.; Chen, J.; Yarilina, A.; Kockeritz, L.; Lu, T.T.; Woodgett, J.R.; Ivashkiv, L.B. IFN-gamma suppresses IL-10 production and synergizes with TLR2 by regulating GSK3 and CREB/AP-1 proteins. Immunity 2006, 24, 563-574. [CrossRef] [PubMed]

60. Ohtani, M.; Nagai, S.; Kondo, S.; Mizuno, S.; Nakamura, K.; Tanabe, M.; Takeuchi, T.; Matsuda, S.; Koyasu, S. Mammalian target of rapamycin and glycogen synthase kinase 3 differentially regulate lipopolysaccharide-induced interleukin-12 production in dendritic cells. Blood 2008, 112, 635-643. [CrossRef] [PubMed]

61. Wang, H.; Brown, J.; Garcia, C.A.; Tang, Y.; Benakanakere, M.R.; Greenway, T.; Alard, P.; Kinane, D.F.; Martin, M. The role of glycogen synthase kinase 3 in regulating ifn-beta-mediated IL-10 production. J. Immunol. 2011, 186, 675-684. [CrossRef] [PubMed]

62. Rodionova, E.; Conzelmann, M.; Maraskovsky, E.; Hess, M.; Kirsch, M.; Giese, T.; Ho, A.D.; Zoller, M.; Dreger, P.; Luft, T. GSK-3 mediates differentiation and activation of proinflammatory dendritic cells. Blood 2007, 109, 1584-1592. [CrossRef] [PubMed]

63. Liu, K.J.; Lee, Y.L.; Yang, Y.Y.; Shih, N.Y.; Ho, C.C.; Wu, Y.C.; Huang, T.S.; Huang, M.C.; Liu, H.C.; Shen, W.W.; et al. Modulation of the development of human monocyte-derived dendritic cells by lithium chloride. J. Cell. Physiol. 2011, 226, 424-433. [CrossRef] [PubMed]

64. Li, M.; Zhang, X.; Zheng, X.; Lian, D.; Zhang, Z.X.; Ge, W.; Yang, J.; Vladau, C.; Suzuki, M.; Chen, D.; et al. Immune modulation and tolerance induction by RelB-silenced dendritic cells through RNA interference. J. Immunol. 2007, 178, 5480-5487. [CrossRef] [PubMed]

65. Shih, V.F.; Davis-Turak, J.; Macal, M.; Huang, J.Q.; Ponomarenko, J.; Kearns, J.D.; Yu, T.; Fagerlund, R.; Asagiri, M.; Zuniga, E.I.; et al. Control of relb during dendritic cell activation integrates canonical and noncanonical NF-kappaB pathways. Nat. Immunol. 2012, 13, 1162-1170. [CrossRef] [PubMed]

66. Ardeshna, K.M.; Pizzey, A.R.; Devereux, S.; Khwaja, A. The PI3 kinase, p38 SAP kinase, and NF-kappaB signal transduction pathways are involved in the survival and maturation of lipopolysaccharide-stimulated human monocyte-derived dendritic cells. Blood 2000, 96, 1039-1046. [PubMed]

67. Zaal, A.; Dieker, M.; Oudenampsen, M.; Turksma, A.W.; Lissenberg-Thunnissen, S.N.; Wouters, D.; van Ham, S.M.; Ten Brinke, A. Anaphylatoxin c5a regulates 6-sulfo-lacnac dendritic cell function in human through crosstalk with toll-like receptor-induced creb signaling. Front. Immunol. 2017, 8, 818. [CrossRef]

68. Armbruster, N.S.; Richardson, J.R.; Schreiner, J.; Klenk, J.; Gunter, M.; Kretschmer, D.; Poschel, S.; Schenke-Layland, K.; Kalbacher, H.; Clark, K.; et al. PSM peptides of staphylococcus aureus activate the p38-creb pathway in dendritic cells, thereby modulating cytokine production and t cell priming. J. Immunol. 2016, 196, 1284-1292. [CrossRef]

69. Marigo, I.; Bosio, E.; Solito, S.; Mesa, C.; Fernandez, A.; Dolcetti, L.; Ugel, S.; Sonda, N.; Bicciato, S.; Falisi, E.; et al. Tumor-induced tolerance and immune suppression depend on the $\mathrm{C} /$ EBPbeta transcription factor. Immunity 2010, 32, 790-802. [CrossRef]

70. Diana, J.; Simoni, Y.; Furio, L.; Beaudoin, L.; Agerberth, B.; Barrat, F.; Lehuen, A. Crosstalk between neutrophils, B-1a cells and plasmacytoid dendritic cells initiates autoimmune diabetes. Nat. Med. 2013, 19, 65-73. [CrossRef]

71. Li, Q.; Xu, B.; Michie, S.A.; Rubins, K.H.; Schreriber, R.D.; McDevitt, H.O. Interferon-alpha initiates type 1 diabetes in nonobese diabetic mice. Proc. Natl. Acad. Sci. USA 2008, 105, 12439-12444. [CrossRef] [PubMed]

72. Zerif, E.; Maalem, A.; Gaudreau, S.; Guindi, C.; Ramzan, M.; Veroneau, S.; Gris, D.; Stankova, J.; Rola-Pleszczynski, M.; Mourad, W.; et al. Constitutively active stat5b signaling confers tolerogenic functions to dendritic cells of nod mice and halts diabetes progression. J. Autoimmun. 2017, 76, 63-74. [CrossRef] [PubMed]

73. Diehl, S.; Anguita, J.; Hoffmeyer, A.; Zapton, T.; Ihle, J.N.; Fikrig, E.; Rincon, M. Inhibition of Th1 differentiation by IL-6 is mediated by SOCS1. Immunity 2000, 13, 805-815. [CrossRef] 
74. Jankovic, D.; Kullberg, M.C.; Hieny, S.; Caspar, P.; Collazo, C.M.; Sher, A. In the absence of IL-12, CD4(+) $\mathrm{T}$ cell responses to intracellular pathogens fail to default to a Th2 pattern and are host protective in an IL-10(-/-) setting. Immunity 2002, 16, 429-439. [CrossRef]

75. Rincon, M.; Anguita, J.; Nakamura, T.; Fikrig, E.; Flavell, R.A. Interleukin (IL)-6 directs the differentiation of IL-4-producing CD4+ T cells. J. Exp. Med. 1997, 185, 461-469. [CrossRef] 